\title{
EN EL LABERINTO. LA CRISIS DE LA RAZÓN FILOSÓFICA EN HUSSERL Y ZUBIRI
}

\author{
ÁNGEL GONZÁLEZ PÉREZ \\ Fundación Xavier Zubiri
}

\begin{abstract}
RESUMEN: Muchas propuestas de filosofía contemporánea convierten la filosofía primera en mera historiografía, o en un análisis del lenguaje, sus dimensiones y sus contextos histórico-sociales, o en un mero recorrido por la historia de un problema y sus diversos desarrollos. El artículo, nombrando esta situación como un estar en el laberinto (el famoso laberinto de Minos) intenta establecer otra base a la filosofía primera entrando en diálogo con dos propuestas muy diversas, aun partiendo del método común de Husserl, su creador (la fenomenología): la búsqueda de una fundamentación en una subjetividad trascendental que opera ya desde el mundo de la vida que realiza Husserl en la crisis de las ciencias europeas y la propuesta de la actualidad de la realidad en el acto intelectivo sentiente de Zubiri con su noología.
\end{abstract}

PALABRAS CLAVE: filosofía primera, geometría, idealización, subjetividad, lebenswelt, entidad, acto, actualidad, inteligencia sentiente.

\section{The crisis of philosophical reason in Husserl and Zubiri}

ABSTRACT: Many proposals for contemporary philosophy change first philosophy into mere historiography, or an analysis of the language, its dimensions and its historical-social contexts, or a mere journey through the history of a problem and its various developments. The article, naming this situation as being in the labyrinth (the famous Minos's labyrinth) attempts to establish another basis to first philosophy entering into dialogue with two very different proposals still departing from the common approach of Husserl, its creator (the Phenomenology): the search for a foundation in a transcendental subjectivity which already operates from the world of life that Husserl carried out in The Crisis of the European Sciences and the proposed reality of actuality in the intellective feeling Act by Zubiri with his noologia.

KEY WORDS: first philosophy, geometry, idealization, subjectivity, lebenswelt, entity, act, actuality, feeling intelligence.

«Ariadna dio un ovillo a Teseo aconsejándole que lo siguiera hasta dar con el monstruo durmiente a quién debía atrapar por el pelo y sacrificar a Poseidón. Después podría encontrar el camino de vuelta volviendo a enrollar el ovillo en sentido inverso»

RoBert GRAVES ${ }^{1}$

1 Robert Graves (2005), Los mitos griegos. Madrid. Grandes obras de la cultura. 


\section{La CRISIS de la RaZÓn EN HusSerL ${ }^{2}$}

\subsection{La génesis de la crisis de la razón en Husserl: Crisis de las ciencias europeas y crisis radical de la humanidad europea (El ovillo de Ariadna)}

Para ello analizaremos las dos primeras partes de La crisis de las ciencias europeas y la fenomenología transcendental.

En la primera parte (parágrafos del 1-7) se conecta programáticamente la crisis de las ciencias europeas con la crisis radical de vida de la humanidad europea, viendo en la primera una expresión de la segunda.

Se comienza abordando una posible objeción al planteamiento. ¿Se puede hablar en serio de crisis de las ciencias europeas viendo sus continuos resultados? ¿No habría que hablar, más bien, de crisis de la filosofía que, como dice Husserl, «actualmente está amenazada de sucumbir al escepticismo, al irracionalismo, al misticismo»? Esto dependerá de cómo entendamos el carácter de cientificidad de las mismas.

Si por cientificidad entendemos su ideal de exactitud y sus resultados, parece que no podemos hablar de tal crisis debido a sus continuos éxitos o resultados. Frente a esto más bien sería la no cientificidad de la filosofía lo que resaltaría.

Pero si por cientificidad se entiende otra cosa además del ideal de exactitud y los resultados, se podrían ver las cosas de otra manera (parágrafo 2 ). Para ver en qué sentido se puede hablar de crisis de las ciencias, y de su cientificidad, hay que mirar a la problemática de una ciencia, la psicología, que muestra en qué sentido podemos hablar de crisis de todas las ciencias, incluida la matemática. Esa crisis no es otra que, frente a lo que las ciencias piensan de sí mismas, ellas viven en una ignorada oscuridad. Esta es la oscuridad de su fundamento último (por lo tanto no es una crisis de método ni de resultado, es una crisis de fundamentos). Una falta de fundamento que muestra la psicología y no es otro que toda la oscuridad del fundamento de las ciencias se basa en la oscuridad sobre la subjetividad, en «el enigma de la subjetividad». En la psicología, como ámbito dominado por el estudio del sujeto y sus operaciones debe de encontrarse el sentido de la crisis de las ciencias y de encontrar su posible salida (hay que aclarar que no se trata de poner a la psicología como fundamento de las ciencias, sino en el hecho de que la psicología y su problemática muestran en qué sentido se puede hablar de crisis de las ciencias y cuál es su posible salida que apunta no a otra cosa que a un nuevo tipo de subjetividad no empírica).

Esta crisis se manifiesta con fuerza en la segunda mitad del siglo XIX, aunque su gestación es anterior como veremos. Según Husserl es en la segunda

2 HusserL, E. (1959), Die Krisis der europäischen Wissenschaften und die transzendentale Phänomenologie. Den Haag. Martinus Nijhoff. Husserliana IV. Citaremos la traducción de Julia V Iribarne: E. Husserl (2008), La crisis de las ciencias europeas y la fenomenología trascendental. Buenos Aires: Prometeo libros. A partir de ahora lo citaremos como KeW y entre paréntesis la paginación de la traducción al castellano. 
mitad del siglo xix cuando las ciencias positivas determinan la visión del hombre en el mundo y, es más, promueven una prosperidad que parecía continua. Las ciencias positivas, que son ciencias de hechos y producen, por lo tanto, hombres de hechos no tenían nada que aportar a los problemas fundamentales del hombre. Estos problemas, señala Husserl, necesitan también una solución fundada. ¿Cuáles son estos problemas? Conviene precisar y Husserl lo hace. Estos problemas son los que «conciernen al hombre en su comportamiento frente al mundo circundante humano y extramundano, el hombre que debe libremente elegir, el hombre que es libre de plasmar racionalmente a sí mismo y al mundo que lo circunda ${ }^{3}$. Obviamente las ciencias de hechos no pueden orientar este comportamiento porque dejan fuera de juego al sujeto (ahora entendemos la referencia a la psicología como ciencia y al misterio de la subjetividad).

Podríamos pensar que quizás las ciencias del espíritu serían capaces de orientar el comportamiento del hombre debido a que estas, en principio, no abstraen del sujeto. Pero no es así tampoco, porque para ellas también se da una abstención del sujeto, ya que consideran que la cientificidad exige de ellas evitar cuidadosamente cualquier toma de posición valorativa y solo consideran como válido aquello que es objetivamente constatable, es decir «lo válido consiste en mostrar todas la formas del mundo espiritual, todos los vínculos de la vida, los ideales, las normas que en cada momento han dado una dirección a los hombres, se han formado y después se han disuelto ${ }^{4}$ sin que por lo tanto haya ningún sentido.

No siempre los interrogantes humanos han estado abandonados por las ciencias y no siempre estas han desconocido las íntimas relaciones que hay entre todas ellas. Comprender los motivos profundos de esta reducción positivista de la ciencia es esencial para entender la crisis radical de vida de la humanidad europea (parágrafo 3).

Para ello hay que mirar al Renacimiento. Allí se inicia un giro revolucionario por el cual la humanidad se vuelve contra sus modos anteriores de existencia, aquellos medievales, los minusvaloran y exige plasmarse a sí misma en plena libertad. Encuentra un modelo de esa exigencia en la humanidad antigua. Sobre este modelo quiere elaborar sus nuevas formas de existencia.

Lo esencial para el hombre antiguo era la "forma filosófica de existencia», la vida teórica, es decir: «el darse su regla libremente a sí mismo, a su vida entera, a partir de la pura razón, a partir de la filosofía» ${ }^{5}$. Para ello hay que efectuar una consideración racional del mundo libre de todo vínculo con el mito y la tradición. Este conocimiento racional significa un conocer, en el mundo mismo, la razón y la teleología que se esconden y su oculto principio. Es decir, el ideal antiguo de la filosofía, consiste en una existencia filosófica dónde el hombre da

3 Husserl, E., KeW. Pág. 5 (50).

4 Ibid.

$5 \quad$ Ibid. p. 5 (51). 
forma (reglas fundadas sobre la razón pura) a su existencia, lo que implica una consideración racional del mundo buscando su razón teleológica. Este ideal se expresa en el platonismo, sobre todo en la figura Sócrates-Platón.

Este se mantiene en los primeros siglos de la época moderna con el ideal de la filosofía como una «ciencia omniabarcadora, el de ciencia de la totalidad de lo que es. Las ciencias al plural, cada una de las cuales debe de ser fundamentada, y todas las que ya están establecidas son sólo ramas dependientes de la única filosofía ${ }^{6}$ como muestra el famoso árbol de Descartes ${ }^{7}$. Pervive en Kant y Husserl lo considera imprescindible para superar la crisis de vida de la humanidad europea. Resumiendo, Husserl considera que el ideal de la filosofía como vida teórica (el theorein) es la cifra espiritual de Europa ${ }^{8}$.

Medido desde este ideal (antiguo y del Renacimiento) el concepto positivístico de la ciencia es un concepto residuo porque deja de lado el problema del sentido del hombre en cuanto ser racional (otra vez el misterio de la subjetividad y el problema de la nueva ciencia, la psicología) o lo que es lo mismo deja de lado los problemas de la razón haciendo referencia a Kant. ¿Qué podemos saber? («de las disciplinas del conocimiento»: del conocimiento verdadero, auténtico y racional) ¿Qué debemos hacer? (de la verdadera y auténtica valoración: los valores auténticos como valores racionales), de la acción ética (la acción verdaderamente buena, la acción fundada sobre la razón práctica) ¿Qué me cabe esperar? Ya que el problema de Dios contiene evidentemente el problema de la razón absoluta en cuanto fuente teleológica del sentido del mundo, como el problema de la inmortalidad del alma y el de la libertad'.

La filosofía del siglo XVIII (parágrafo 4), la época de la ilustración, llevada por ese ideal recuperado en el Renacimiento «tomó forma impactante de filosofía sistemática, pero lamentablemente no unificaba, sino que separaba los sistemas uno de otro ${ }^{10}$. Y al no alcanzar a responder satisfactoriamente a esos

\section{Ibid. p. 6 (52).}

7 En una carta al traductor de sus Principios de filosofía Descartes compara el orden de las ciencias a un árbol dónde la metafísica formaría las raíces, la física el tronco, la medicina, la mecánica y la moral las ramas principales: «Así la filosofía toda es como un árbol, cuyas raíces son la metafísica, cuyo tronco es la física y cuyas ramas, brotando de este tronco son todas las demás ciencias, las cuales se reducen a tres principales, a saber, la medicina, la mecánica y la moral». Cfr. Descartes (1987), Carta del autor a quien tradujo los principios de la filosofía. México: UNAM. pp. 15-16.

8 Cfr. Paolo Bucci (2013), La Crisi delle scienze europee di Husserl. Roma: Carocci editore: «Per sufragare la tesi della filosofia come cifra spirituale dell'Europa, como fattore costitutivo della sua identità culturale, Husserl non fa che riproporre il topos della irreducibile originalità del theorein, dell'atteggiamento teorerico introdotto dalla filosofia greca como atteggiamento que segna una netta cesura rispetto alla concezione mitico-religiose del mondo», p. 48. Este libro junto con F. SAVERIo (2012), Guida alla lettura della Crisi delle sciencie europee. Roma-Bari: Laterza, son dos útiles introducciones al libro de Husserl.

9 Cfr. Kant, E. (1919), Kritik der reinen Vernunft. Leipzig: Felix Meiner. p. 666. Traducción castellana de Pedro Rivas. I. Kant (1978), Crítica a la razón pura. Madrid: Alfaguara. p. 630 (A 805/ B 833): el canon de la razón.

10 Husserl, E., KeW. p. 8 (54). 
problemas de la razón (problemas del hombre, por lo tanto) la fe en el ideal de la filosofía y del método vacila. Este fracaso es debido a que los propios investigadores interesados en los problemas metafísicos aceptaron «el ideal dominante», no el ideal dominante de la filosofía antigua y del Renacimiento. ¿Cuál entonces? (parágrafo 5).

La época moderna se inicia con un ideal definido: el de una filosofía universal y un método adecuado. El fallo de este ideal tiene muchas dimensiones que el parágrafo quinto recorre. Conviene subrayar primero las dos principales vertientes. Por un lado el fallo de este ideal tuvo como consecuencia que la filosofía se convirtió en un problema para sí misma. El problema de la posibilidad de la metafísica. Lo que, como ya hemos resaltado, implicaba el problema de toda la racionalidad (¿Qué puedo conocer? ¿Qué debo hacer? ¿Qué me cabe esperar?). Pero con ello, por otro lado, las ciencias particulares también se encontraron en una crisis particular sentida como enigmática. Una crisis de fundamentos. Se trata de que el problema del ideal de la filosofía implicaba de facto la posibilidad de las ciencias de hechos ya que estas sólo encontraban su relación entre ellas y su sentido dentro del ser y de las regiones del ser delimitados por la filosofía primera o metafísica. En palabras de Husserl: «¿Es necesario separar razón y existente cuando la razón determina lo que el existente es?» ${ }^{11}$. Al separarse la razón filosófica de las ciencias que investigan los entes (existentes en la traducción de Julia V. Iribarne) en sus diversas regiones estas últimas se convierten, como ya subrayo antes Husserl, en meras ciencias de hechos además de perseguir sus finalidades teóricas sin ninguna referencia a los interrogantes sobre el sentido humano. Esta crisis de la filosofía, con su consecuente crisis de las ciencias positivas, implica la crisis en la fe en la razón:

«que en última instancia da sentido a todo ser mentado, a todas las cosas, valores, fines, vale decir su referencia normativa respecto a aquello que desde el comienzo de la filosofía designa la palabra verdad — verdad en sí- y correlativamente la palabra existente (seindes) óntos on. Con esto cae también la creencia en una razón "absoluta" a partir del cual el mundo adquiere su sentido» ${ }^{12}$.

Aquí aparece con claridad la dirección de Husserl de recuperar la razón de una subjetividad no empírica "que da sentido al mundo». Este es el punto clave de Husserl, a nuestro modo de ver: la crisis de las ciencias europeas tiene su raíz en ese «misterio de la subjetividad», una subjetividad no empírica, que desde su racionalidad determina el ente.

Pero perder esta fe significa también perder la creencia «en sí mismo», en el verdadero ser que le es propio, un verdadero ser que, criticando a Descartes, no lo tiene desde siempre con «la evidencia del yo soy»:

«la “creencia en sí mismo”, en lo que para él es su ser propio y verdadero, que él no ha tenido siempre, ni siguiera con la evidencia del "yo soy", sino que

$11 \quad$ Ibíd. p. 9 (55)

12 Ibid. pp. 10-11 (56). 
ahora tiene y puede tener en la forma de lucha por la verdad, para hacerse a sí mismo verdadero. Por encima de todo, el ser verdadero es un fin ideal, una tarea de episteme, de la "razón" puesta frente al ser "obvio", no-cuestionado en la doxa, el ser meramente mentado» ${ }^{13}$.

Finalmente esta crisis de la filosofía implica también una problematicidad del mundo: «el problema de las conexiones profundas y esenciales de la razón y del ente en general». Lo que Husserl llama «el enigma de todos los enigmas».

Esta crisis con sus dimensiones nos sitúa como filósofos, si todavía esta palabra tiene sentido, en una contradicción existencial que consiste por un lado en «la voluntad de ser una humanidad fundada sobre la razón filosófica» y por otro en la conciencia de que este telos se realiza históricamente. Esta contradicción debe llevarnos a afirmar que el racionalismo del siglo xvIII, es decir, el modo según el cual pretendía realizar el ideal de la razón era ingenuo y era un momento del movimiento infinito de la razón latente a la razón histórica, pero no debe llevarnos a caer en el irracionalismo (parágrafo 6 y 7 ).

La crisis de Europa está no en una crisis de la razón, sino en una crisis de un modo de ser realizada y es a este modo al que va a dedicar la segunda parte de La crisis de las ciencias europeas.

\subsection{El origen de la crisis de la vida de la humanidad europea como una tensión no resuelta entre objetivismo fisicalista y subjetividad transcendental (En el corazón del laberinto: sacrificando al monstruo)}

Antes de abordar esta segunda parte (que va de los parágrafos 8 al 27) y que lleva el nombre de El origen del contraste moderno entre objetivismo fisicalístico y subjetivismo transcendental, conviene ver su sentido profundo para no perdernos en el bosque de sus argumentaciones y este está señalado en la primera parte del parágrafo 14 .

En este parágrafo se indica qué se entiende por objetivismo del que después estudiara su génesis en los parágrafos del 8 al 10 dedicados a la física de Galileo $^{14}$. Por objetivismo se entiende aquella dirección del pensamiento que se mueve sobre «el terreno del mundo ya dado como obvio en la experiencia y de perseguir la "verdad objetiva", lo que en él es incondicionalmente válido para todo sujeto racional, es decir, lo que eso es en sí mismo». Con ello se alcanzaría el ente en su ultimidad, ir más allá (meta-física) sería un sin-sentido, no tendría sentido racional. Dicho de otra forma, objetivista es un modo, una dirección del pensamiento que:

13 Ibíd. p. 11 (56).

14 Para el estudio de Galileo, Husserl utilizó, aunque no lo cite, a Ernst Cassirer y su monumental obra sobre el problema del conocimiento humano. Sobre todo el volumen primero. E. Cassirer (1986), El problema del conocimiento. México: FCE. Volumen I: El renacer del problema del conocimiento. El descubrimiento del concepto de la naturaleza. Los fundamentos del idealismo. pp. 344-401. 
a. Se mueve en un terreno del mundo como ya dado, como obvio en la experiencia sin cuestionarlo, es decir, como veremos, sin indagar los modos en el cual eso está dado a la subjetividad. Esto no afectaría sólo al objetivismo científico sino también a un pensamiento objetivista propio de la experiencia precientifica del mundo.

b. Persigue en ese terreno del mundo ya obvio «verdades objetivas». Entendiendo por tales lo que en el mundo es incondicionalmente válido para todo sujeto racional.

c. Con ello sería alcanzado el ente en su ultimidad, ir más allá carece de sentido.

Resumiendo, el sentido del ser ha de buscarse en lo obvio como verdad objetiva, es decir, como lo incondicionalmente válido para todo sujeto racional.

En los parágrafos del 8 al 10 se pretende analizar la génesis de esta orientación del pensar en la matematización galileana de la naturaleza.

Al objetivismo se contrapone el subjetivismo transcendental que afirma que:

«el sentido del ser del mundo de la vida pre-dado es una configuración subjetiva, que resulta de la vida experienciante, pre-científica. En ella se construye el sentido y la validez de ser del mundo, y en cada caso del mundo que efectivamente vale para quien tiene la experiencia correspondiente» ${ }^{15}$.

Dicho de otra forma:

a. Se mueve en el terreno del mundo como ya dado, pero ese mundo ya dado es el mundo de la vida (en un sentido que ya precisaremos).

b. La verdad de ese mundo de la vida ya dado no es una verdad objetiva, sino una formación subjetiva, una operación de la vida efectuante.

c. Con ello sólo se alcanza lo dado en el mundo de la vida si se va más allá hacía la subjetividad, hacía la formación subjetiva que lo efectúa.

Resumiendo, el sentido del ser ha de buscarse en la vida efectuante, en la subjetividad que lo realiza que es la que construye el sentido y la validez del mundo.

¿Y el mundo objetivamente verdadero de la ciencia? Este mundo es una formación del grado más alto fundada sobre la experiencia y el pensamiento precientífico, es decir, sobre las operaciones de validez.

Dicho en palabras de Husserl, lo primero en sí no es el ser del mundo en su indudable obviedad. Lo primero en sí es la subjetividad en cuanto esta pone ingenuamente el ser del mundo (mundo de la vida) y después lo racionaliza (mundo de las objetividades científicas) o, lo que es lo mismo, lo objetiviza.

15 Cfr. Husserl, E., KeW. p. 70 (112). 
Pero el sentido de esta subjetividad solo puede ser superado si no se identifica con el hombre, con la subjetividad psicológica. Hay que convertir la subjetividad psicológica en subjetividad transcendental. En el primer caso solo sería un idealismo psicológico. El verdadero subjetivismo transcendental critica la pretensión de legitimidad de la ciencia objetiva como filosofía última, pero al mismo tiempo pretende una cientificidad de tipo nuevo, una cientificidad transcendental. Esta cientificidad, cosa que desborda los límites de este artículo, solo podrá ser alcanzada por la fenomenología.

Resumiendo el modo de pensar objetivista se manifiesta con el nacimiento de la ciencia moderna y con el afirmarse de la nueva ciencia galileana. El modo de pensar propio de la subjetividad transcendental, como telos escondido de la filosofía moderna, encuentra expresión en la reflexión gnoseológica que toma inicio en el cogito cartesiano para llegar hasta Kant ${ }^{16}$.

Este modo de pensar objetivista se da en tres pasos. Vamos a verlos brevemente:

a) Consolidación de la geometría pura: (8-9a).

b) La geometrización del espacio físico y matematización de la naturaleza (9b-e).

c) La algebraización de la geometría y la matemática (9f-g).

Empezando por la consolidación de la geometría pura: (8-9a). Lo primero que hay que señalar es que en la época moderna se da una poderosa transformación de sentido dando tareas o funciones universales a la matemática, dotándola de principios nuevos completamente extraños a la matemática y geometría antigua.

Es verdad que los antiguos, guiados primero por la doctrina platónica de las ideas y después por la geometría de Euclides, ya habían dado pasos en esta transformación que explicaremos, pero lo habían hecho de forma limitada.

Con la teoría platónica de las ideas se habían:

«idealizado los números empíricos, las dimensiones de las magnitudes, las figuras espaciales empíricas, los puntos, líneas, superficies, cuerpos; junto con esto las proposiciones y las demostraciones de la geometría se transformaron en proposiciones y demostraciones ideal-geométricas» ${ }^{17}$.

Con Euclides nace:

«la idea altamente impresionante de una teoría deductiva, sistemáticamente unitaria, dirigida a un fin ideal amplio y elevado, que se apoyaba en conceptos fundamentales axiomáticos, en inferencias apodícticas progresivas, un todo a partir de la pura racionalidad, un todo de puras verdades incondicionadas, inmediata y mediatamente evidente, discernible en su verdad incondicionada ${ }^{18}$.

16 Bucci, P. Op.cit, p. 54.

17 Husserl, E., KeW. p. 18 (63-64).

18 Ibíd. pp. 18-19 (63-64). 
Pero ambas, junto con la silogística aristotélica, solo conocen tareas finitas, «un a priori finitamente cerrado».

La novedad está en el concepto de espacio geométrico y que ella se constituye en ciencia de ese espacio (este será el vínculo con Descartes).

A este espacio ideal apriórico y unitario (dos características que no corresponden al espacio vivido y por lo tanto hacen de este espacio algo no ligado a la experiencia) le corresponde:

«una teoría unitaria sistemática, infinita y, a pesar de la infinitud, cerrada en sí misma, la que ascendiendo a partir de conceptos y proposiciones axiomáticas permite construir toda forma imaginable, pensable en el espacio, en univocidad deductiva ${ }^{19}$.

En conclusión: nuestro pensamiento descubre según conceptos, proposiciones, conclusiones, demostraciones... lo que de antemano, en sí, está ya en la verdad, lo que en el espacio geométrico existe idealmente.

Pero esto no ocurre solo para el espacio ideal. Más extraña era para los antiguos una matemática puramente formal que se inicia con el mundo moderno y conducirá a los comienzos del algebra. Con la matematización galileana de la naturaleza se va a dar un paso más. La misma naturaleza va a ser idealizada bajo la guía de la nueva matemática (parágrafo 9).

En nuestra experiencia cotidiana el mundo nos es dado de modo subjetivorelativo. Cada uno «de nosotros tiene sus apariciones y, para cada uno ellas valen como lo que efectivamente es». Pero esto no quiere decir que nosotros pensemos que haya muchos mundos, más bien creemos que es el mundo con las mismas cosas, sólo que a cada uno se le aparecen de forma diferente. Este es un presupuesto obvio que Galileo aceptó: la idea necesaria, vacía, de cosas en sí objetivamente existentes con un contenido que debemos atribuir a las cosas mismas.

¿Cómo consigue Galileo matematizar ese mundo que nos es dado de modo subjetivo-relativo a cada uno?

Para ello Husserl vuelve a la formación de la geometría pura, a la matemática pura de las formas espacio-temporales y a su génesis (parágrafo 9a). En el mundo circundante intuitivo nosotros «experienciamos cuerpos (...), no cuerpos geométrico-ideales sino precisamente los cuerpos que efectivamente experienciamos, y con el contenido que es el efectivo contenido de la experiencia ${ }^{20}$.

Estos cuerpos pueden ser modificados con la fantasía. Pero con esto a lo sumo alcanzamos un espacio fantástico (piénsese en los espacios de Escher): la fantasía solo puede transformar formas sensibles en otras formas sensibles. Pero el espacio geométrico no es el espacio fantaseado. El espacio geométrico esta hecho de formas puras que pueden diseñarse en el espacio ideal: cuerpos puros, rectas puras, superficies puras... ¿Cómo se alcanza esto? Por el método de la idealización. Las cosas del mundo que nos rodea están inmersas, en todas

19 Ibíd. p. 19 (64)

$20 \quad$ Ibíd. p. $22(67)$ 
sus propiedades, en una oscilación de lo meramente típico: «su identidad consigo mismas, su ser igual-en-si-mismas y su igualdad en la duración temporal es meramente aproximada, tanto como su ser igual a otro» ${ }^{21}$.

Esta tipicidad, esta aproximación de las cosas entre ellas admite una graduación de mayor o menor perfección. Sobre la base de este perfeccionamiento se van delineando por todas partes formas límites «hacia las que se dirige la correspondiente serie de perfeccionamiento como hacia polos invariantes y nunca alcanzados ${ }^{22}$. Sobre esas formas invariantes espaciales se constituye la geometra: «nosotros, "geómetras" estamos interesados por estas formas ideales $\mathrm{y}$, consecuentemente ocupados con estas para determinarlas y construir nuevas sobre las ya determinadas ${ }^{23}$.

En lugar de la praxis real tenemos ahora la praxis ideal de un pensamiento puro que se mantiene en el ámbito de las puras formas-límite. Una vez construidas estas formas-límite se convierten en productos habituales y disponibles intersubjetivamente mediante los cuales es posible siempre lo nuevo: «un mundo infinito y sin embargo en-si cerrado, de objetividades ideales como campo de trabajo ${ }^{24}$.

Este proceso de idealización, con esta práctica matemática, pretende alcanzar lo que no es posible en la práctica empírica la «exactitud». Ya que para las formas ideales «se da la posibilidad de determinarlas en identidad absoluta, de reconocerlas como sustrato de cualidades (Beschaffenheiten) absolutamente idénticas y determinables de forma metódica y unívoca» ${ }^{25}$.

Añadamos un ejemplo, aportado por Lonergan, para que este método geométrico no quede expresado de un modo tan formal. Como todo estudiante sabe una circunferencia es el lugar de los puntos equidistantes de un centro en el plano. Pero ¿Cómo se ha llegado a ello?:

«imaginemos una rueda de carreta, con su cubo masivo, sus gruesos rayos y su llanta sólida. Hagamos una pregunta: ¿Por qué es redonda? Acotemos la pregunta. Lo que buscamos es la razón inmanente o el fundamento de la redondez de la rueda. Por lo tanto una respuesta correcta no añadirá nuevos datos tales, como la carretera, el acarreo, la transportación, los carpinteros o sus herramientas. La pregunta se referirá únicamente a la rueda. Consideremos esta sugerencia. La rueda es redonda porque sus rayos son iguales. Es claro que eso no basta: los rayos bien podrían ser iguales, pero estar encajados disparejamente en el cubo y en la llanta; además la llanta podría ser plana entre rayos sucesivos. Con todo, tenemos una pista. Hagamos que el cubo se reduzca hasta ser un punto; hagamos que los rayos y las llantas se adelgacen hasta convertirse en líneas; entonces, si hubiese infinitos rayos y todos fuesen exactamente iguales, la llanta podría ser perfectamente redonda; por el contrario si alguno de los rayos fuese disparejo, la llanta no podría carecer

\footnotetext{
21 Ibid.

22 Ibid. p. 23 (68).

23 Ibid.

24 Ibid.

25 Ibid. p. 24 (69).
} 
de protuberancias o abolladuras. Por tanto, podemos decir que la rueda es necesariamente redonda en tanto la distancia del centro del cubo al exterior de la llanta es siempre igual» ${ }^{26}$.

Esto nos acerca bastante a la definición de circunferencia. Aquí podemos ver en funcionamiento el método geométrico. Las cosas de la vida cotidiana, las ruedas por ejemplo, están inmersas en una oscilación (nunca hay dos ruedas iguales en todas sus propiedades. Una rueda concreta no puede ser utilizada como definición o medida de la redondez de las ruedas). Pero podemos ver en la redondez de las diversas ruedas una aproximación a la perfección de la redondez, al ideal de la redondez misma. Sobre esta base de perfeccionamiento se delinea la forma ideal límite, el ideal de redondez o circunferencia, a la que tienden todas las ruedas: la figura geométrica en la que la distancia del centro del cubo al exterior del mismo es siempre igual. A esto se llega por un proceso de «idealización» en términos de Husserl, que podríamos matizar siguiendo a Lonergan, a propósito de la redondez de la rueda, con las siguientes observaciones.

Primero: los puntos y las líneas no pueden ser imaginados (por eso dice Husserl que este proceso de idealización no es un proceso de la imaginación o la fantasía ya que esta sólo alcanzaría un nuevo espació fantástico, pero no el espacio geométrico). Podemos, señala Lonergan,

«imaginar un punto pequeño en extremo. Pero, al margen, de que algo tan pequeño fuese un punto, aún tendría magnitud. Podemos imaginar un hilo fino en extremo. Pero, al margen, de que algo tan fino fuese un hilo, aún tendría grosor, anchura y longitud. Eliminemos de la imagen todo grosor y anchura, y se desvanecerá también la longitud ${ }^{27}$.

Segundo: las líneas y puntos son conceptos, por lo tanto, no meras imágenes creadas, y esto es la idealización a través de la suposición. Por ejemplo: «el punto imaginado tiene magnitud y posición, pero el geómetra dice "supongamos que sólo tenga posición”. La línea imaginada tiene anchura y longitud, pero el geómetra dice: "Supongamos que sólo tenga longitud" ${ }^{28}$. Estas suposiciones no son azarosas sino necesarias para la meta buscada:

"¿Por qué fue necesario que el cubo se redujera a un punto y los rayos y las llantas a meras líneas? Porque contábamos con una pista —la igualdad de los rayos - y estábamos aprovechando todo lo que daba de sí. Mientras el cubo tuviera alguna magnitud, los rayos podían encajar en él disparejamente. Mientras los rayos tuvieran anchura, la rueda podía ser plana en sus extremos. Por eso, postulamos un punto sin magnitud y unas líneas sin anchura, para obtener una curva que fuera por necesidad perfectamente redonda» ${ }^{29}$.

26 Lonergan, B. (2004), Insight. Estudio sobre la comprensión humana. Salamanca: Sígueme, pp. 41-42.

27 Lonergan, B. Op.cit, p.42.

28 Ibid. p. 43.

29 Ibíd. 
Tercero: pero, a pesar de todo, la imagen es necesaria para aprehender, comprender, la necesidad de la definición de esa redondez por el acto intelectivo:

«al acercarnos a la definición de la circunferencia, ocurrió cierta aprehensión de una necesidad y de una imposibilidad. Como hemos subrayado, si todos los radios son iguales, la curva tiene que ser perfectamente redonda; y si algunos radios son desiguales, la curva no puede carecer de protuberancias o abolladuras. Además, la necesidad en cuestión no era una necesidad en general, sino una necesidad de redondez que resulta de estos radios iguales. Asimismo, la imposibilidad en cuestión no era una imposibilidad en abstracto, sino una imposibilidad de redondez que resulta de estos radios desiguales. Eliminemos la imagen del centro, los radios, la curva, y de inmediato se desvanecerá toda aprehensión de una redondez necesaria o imposible» ${ }^{30}$.

Cuarto: esta definición de circunferencia alcanzada por el proceso de idealización, como diría Husserl, es una definición explicativa, no meramente nominal. ¿Por qué es esto así? Porque una vez construidas estas formas ideales se convierten, como diría Husserl, en productos disponibles con los cuales es siempre posible crear lo nuevo:

«tanto las definiciones nominales como las explicativas suponen actos de intelección. Pero una definición nominal no supone más que una intelección sobre el uso correcto del lenguaje. Una definición explicativa, en cambio, supone un acto de intelección ulterior sobre los objetos a los cuales se refiere el lenguaje. El nombre "circunferencia" se define como una curva plana perfectamente redonda, igual que el nombre "línea recta" se define como una línea que se halla tendida uniformemente entre sus extremos. Pero, cuando procedemos a afirmar que todos los radios de una circunferencia son iguales o que todos los ángulos rectos son iguales, ya no estamos hablando únicamente de nombres. Estamos formando asertos sobre los objetos designados por los nombres» ${ }^{31}$.

Volviendo del ejemplo a Husserl, este método geométrico, aunque no se sea consciente, remite al método de determinar lo medido y «que mide en general ya en el mundo de la vida precientíficamente intuido». Es el arte de medir que:

«descubre prácticamente la posibilidad de elegir como medida ciertas formas básicas empíricas (codos, pies etc.), instaladas concretamente en cuerpos empíricamente fijos, universalmente disponibles de modo fáctico, y determinar intersubjetivamente y de modo prácticamente unívoco por medio de las relaciones que existen (...) entre ellos y otras formas corporales, estas otras formas (por ejemplo esto mide diez codos o pies) $\aleph^{32}$.

Una vez visto como se constituye la geometría pura, hay que ver la geometrización del espacio físico y la matematización de la naturaleza (parágrafo 9b-e). El paso fue posible porque en parte ya se había realizado. La geometría que se

$30 \quad$ Ibid. p. 44.

31 Ibid. pp. 46-47.

32 Cfr. Husserl, E., KeW. p. 25 (70). 
encontró Galileo ya poseía una amplia aplicación terrestre y astronómica. Por lo tanto ya Galileo tenía el camino abierto para relacionar «lo empírico con las ideas límites matemáticas» (parágrafo 9b).

Galileo, apoyado en lo anterior se dijo, según Husserl, siempre que utilicemos este método habremos superado la relatividad de las concepciones subjetivas que es esencial al mundo empírico intuitivo.

Pero esta matemática (ese método) se ocupa de cuerpos y del mundo corporal en una abstracción, es decir, se ocupa de formas abstractas. En el mundo de la vida, sin embargo, las formas realmente efectivas y empíricas posibles se nos dan como formas de una materia de un contenido sensible (la circunferencia lo es de una rueda o de la luna llena, por ejemplo; la línea recta lo es de una calle o de una carretera por los campos de Castilla). Por lo tanto, las formas se nos presentan con las denominadas cualidades sensibles: color, tono, aroma y similares.

Además estas cosas corpóreas del mundo circundante, con sus denominadas cualidades sensibles, se nos presentan, por decirlo así, en el mundo de la vida con:

«sus "costumbres" de comportarse de modo semejante en circunstancias similares. Si tomamos el mundo intuido globalmente en su momentaneidad fluyente (jeweligkeit), en el cual, para nosotros, él está simplemente ahí, entonces tiene también como totalidad su "costumbre", esto es, continuar habitualmente como hasta ahora. Así nuestro mundo circundante empíricamente intuido tiene un estilo global empírico» ${ }^{33}$.

Es decir, las cosas y sus acaecimientos no transcurren arbitrariamente, sino que están vinculados por un estilo: ese estilo es «una regulación causal universal de todo lo coexistente (zusammen-seinde)» por la cual el mundo no es meramente una totalidad sino una unidad total (Allenheit).

Sobre la base de este estilo causal del mundo circundante intuido es posible formular hipótesis, inducciones, previsiones con respecto a lo desconocido del pasado, del presente y del futuro (puedo prevenir que un cielo altamente nublado y con unas temperaturas muy bajas conlleva un día no muy recomendable para hacer un viaje largo en coche o, de hacerlo, tomar precauciones llevando cadenas, el depósito lleno, el móvil con la carga plena...). Pero estas previsiones no son más que costumbres (Husserl está aquí citando a Hume, evidentemente, sin hacerlo explícito).

Pero con esto no llegamos a la física de Galileo. La física de Galileo toma parte en esos presupuestos pero necesita dar un paso más. Sólo podemos llegar a este conocimiento físico si se descubre «un método para construir el mundo y la infinitud de sus causalidades, sistemáticamente, en cierta medida de antemano, a partir del escaso haber, en cada caso, de experiencia directa» ${ }^{34}$.

33 Ibid. p. 28 (73).

34 Ibid. p. 29 (74). 
Este paso lo va a dar Galileo utilizando las vías que ya había abierto la matemática de un doble modo.

Primero mediante la idealización del mundo corporal que como ya hemos visto consiste en que por primera vez «una infinidad de objetos subjetivo-relativos y sólo pensados en una vaga representación general, con un método a priori omniabarcador sería realmente pensable, objetivamente, determinable y como en sí determinado» ${ }^{35}$.

Segundo, esa infinidad de objetos subjetivo-relativos puede ser objetivamente determinable por el arte de la medida ya que:

«todas las cosas del mundo empíricamente intuido tienen corporeidad según el estilo del mundo, son "res extensae", experienciadas en ubicaciones mutables que, consideradas como totalidad en cualquier momento tienen su ubicación conjunta, y en las que los cuerpos singulares tienen su ubicación relativa etc.; en virtud de la matemática pura y del arte práctico de la medida se puede crear para todo lo extenso similar en el mundo de los cuerpos, una previsión inductiva de tipo enteramente nuevo, vale a decir que en cada caso se puede "calcular" con necesidad rigurosa, a partir de acontecimientos de forma dados y medidos, otros desconocidos y nunca accesibles de forma directa ${ }^{36}$.

Es decir no tenemos una previsión, como en el mundo circundante, de una cierta habitualidad del mundo, sino una previsión que calcula con necesidad rigurosa.

Pero la dificultad para este proceso, y es lo que vamos a ver ahora, es qué hacemos con las cualidades sensibles "específicas» de las que hemos hablado antes (colores, olores, sonidos...), que no pueden ser tan idealizadas como la extensión, la «res extensae». Para ello, y esto es lo que va a realizar la física de Galileo, hay que matematizar indirectamente esas cualidades sensibles. Pero ¿qué significa esta matematización indirecta? (parágrafo 9c).

Matematizar estas cualidades sensibles que Husserl llama «contenidos» implica dificultades porque aunque tienen una medida, es decir, podemos hablar de graduaciones (de frío o de calor, de aspereza o lisura, de claridad u oscuridad...), esa medida no es exacta. Esta exactitud puede ser alcanzada dentro de la extensión ya que:

«tenemos sólo una, no una forma universal doble del mundo, sólo una y no una geometría doble, es decir, no una geometría de las formas y una segunda forma de los contenidos. Los cuerpos del mundo empírico intuido según estructura del mundo que le pertenece a priori, están hechos de tal modo que cada cuerpo tiene su extensión — dicho abstractamente- como propia, pero todas estas extensiones son formas de la extensión una, total, infinita del mundo. Como mundo, como configuración universal de todos los cuerpos,

35 Ibid. p. 30 (74).

36 Ibid. pp. 30-31 (75). 
éste tiene, pues, una forma total abarcadora de todas las formas, y en el modo analizado, ésta es idealizable y dominable mediante construcción ${ }^{37}$.

Pero las cualidades sensibles de los cuerpos (los «contenidos»), no pueden ser matematizadas directamente porque estas configuraciones no son idealizables de forma análoga a las formas espacio-temporales (por ejemplo: metros, líneas, rectángulos, minutos, segundos ...) y además el concepto de aproximación tampoco tiene el mismo sentido de exactitud en las formas espaciales que en los contenidos sensibles (no hay, en principio, una medida exacta de los olores o de los sabores, tal vez una graduación aproximativa).

¿Cómo se da esa matematización indirecta? Reduciendo los contenidos (calor, color por ejemplo) a manifestaciones de la extensión que sí pueden ser medidas:

«lo que nosotros mismos experienciamos en la vida pre-científica en las cosas, como colores, tonos, calores, como pesos, causalmente como irradiación de calor de un cuerpo que calienta los cuerpos que lo rodean y cosas semejantes, eso indica naturalmente "fisicalísticamente": vibraciones de tono, vibraciones de calor, por lo tanto acontecimientos puros del mundo de las formas» ${ }^{38}$.

De este modo la naturaleza infinita como universo concreto de causalidad se convirtió en una matemática aplicada de modo peculiar.

Aunque en cada caso haya de ocuparse o tratar con lo fáctico-individual, el método tiene de antemano un sentido general. La matematización indirecta del mundo produce fórmulas generales numerales que, una vez encontradas, pueden servir, aplicándolas para subsumir casos particulares.

El último paso es la algebraización de la geometría y la matemática (parágrafo 9f-g). El paso siguiente consiste en que una vez se tienen las fórmulas se posee de antemano la previsión de la certeza empírica.

Nos detenemos aquí en nuestro análisis del objetivismo que tiene su raíz en la física de Galileo. Saquemos algunas ideas claves antes de abordar el análisis de la teoría del conocimiento moderno, muy influida, en un doble sentido como veremos, por el objetivismo de la física de Galileo:

1. Una es la vida circundante que nos rodea en cuanto forma parte de nuestra experiencia precientifica del mundo, de un mundo circundante intersubjetivo, que se constituye a través de la correlación y corrección recíproca de las experiencias perceptivas individuales. Esta es una naturaleza descriptiva que parte del mundo circundante de cada hombre y que viene representada de forma no matemática sino a través de relaciones esenciales con la vida de cada uno: comportamientos, hábitos... como subraya Heidegger en Sein und Zeit con su ejemplo del martillo ${ }^{39}$. Como subraya Heidegger las cosas con las cuales nos las

37 Ibid. p. 33 (77).

38 Ibíd. p. 35 (79).

39 Cfr. Heidegger, M. (2006), Sein und Zeit. Tübingen: Max Niemeyer Verlag. pp. 66-72. 
tenemos que haber no son sobre todo objetos de un conocimiento que se determina de una forma teórica, sino que esas cosas se configuran como aquello que viene usado, manejado, manipulado a través de nuestras prácticas ${ }^{40}$.

2. Otra es el mundo físico, la naturaleza de la que se ocupa la física matemática. Esta es una naturaleza exacta.

3. La segunda se separa de la primera a través de un proceso de idealización que conlleva el origen de la geometría, a través de una aplicación directa, respecto a la res extensae, e indirecta, en las cualidades sensibles, de las idealidades matemáticas y geométricas y, en último término, a través de las fórmulas algebraicas.

Esta separación tiene consecuencias negativas. Por un lado, la expulsión del ámbito de la ciencia de las cualidades sensibles a través de su reducción a representaciones meramente subjetivas de la realidad física y a lo sumo solo conservan un valor en la medida en que son reducidas a una manifestación de otra cosa susceptible de ser medida exactamente. Pero hay, por otro lado, todavía una consecuencia más importante que tiene que ver con ese «misterio de la subjetividad» del que hablamos al principio, con esa crisis de la vida europea ligada a ese «misterio de la subjetividad» y con esa ciencia de hechos que sólo produce hombres de meros hechos y es (parágrafos del 10-13) un dualismo dominante en la ciencia moderna que se traspasa al pensamiento filosófico a través de Descartes.

Galileo:

«considerando el mundo en base a la geometría, y a partir de éste, en base a lo que aparece sensiblemente y es matematizable hace abstracción de los sujetos como personas con una vida personal, de todo lo espiritual, en cualquier sentido, de todas las cualidades culturales que las cosas asumen en la práctica humana. De esta abstracción resultan las puras cosas corporales, que, empero, como realidades concretas y en su totalidad (...) devienen mundo. Bien se puede decir que solo a través de Galileo sale a la luz la idea de una naturaleza como la de un mundo corpóreo realmente cerrado (...) en la que todo acontecer está determinado de antemano y unívocamente ${ }^{41}$ (parágrafo 10).

Es decir, con Galileo, se produjo «una transformación completa de la idea de mundo». Este se desdobla en dos mundos: "el mundo natural y el anímico. De los que este último, sin duda, mediante el tipo de su referencia a la naturaleza no llega a ninguna mundanidad independiente ${ }^{42}$. El mundo de la vida personal que con su praxis dota de sentido a las cosas (el sentido por lo tanto no les pertenece a ellas de suyo) y el mundo corpóreo cerrado y causalmente determinado donde reina la necesidad.

40 Para todo esto el magnífico comentario de Sein und Zeit de Adriano Fabris. Cfr. FABRIs, A. (2000), Essero e tempo. Introduzione alla lettura. Roma: Carocci.

41 Cfr. Husserl, E., KeW. pp. 60-61 (103).

42 Ibíd. p. 61 (103). 
Dado que sobre este segundo mundo había demostrado su éxito la matemática pura (en el sentido anteriormente demostrado) ¿no debía extenderse su modo de conocimiento a todas las esferas? Esa fue la conclusión que sacó Descartes.

Y desde este punto se empezó a plantear una nueva psicología «que atribuya al alma un modo de ser propio por principio semejante al de la naturaleza ${ }^{43}$ (parágrafo 11). Esta naturalización se inicia con Hobbes y pasa por J. Locke con la «metáfora del white paper y de la tabula rasa a la que los datos anímicos llegan y pasan, regulados de un modo semejante a los procesos corporales de la naturaleza ${ }^{44}$.

Pero también a la filosofía. Esta desde sus inicios aspira a ser «ciencia», conocimiento universal del universo, de lo que existe, no un conocimiento vago y relativo (doxa), sino conocimiento racional (episteme) y este ideal solo era posible, visto sus resultados, de acuerdo con el modelo de la matemática reconfigurada y de la ciencia de la naturaleza (parágrafo 12).

El fracaso de este intento va conduciendo a la filosofía hacia un subjetivismo transcendental que afirma que:

«el sentido del ser del mundo de la vida pre-dado es una configuración subjetiva, que resulta de la vida experienciante, pre-científica. En ella se construye el sentido y la validez del ser del mundo, y en cada caso del mundo que efectivamente vale para quien tiene la experiencia correspondiente» ${ }^{45}$.

Dicho de otra forma:

a. Se mueve en el terreno del mundo como ya dado, pero ese mundo ya dado es el mundo de la vida (en un sentido que ya precisaremos).

b. La verdad de ese mundo de la vida ya dado no es una verdad objetiva, sino una formación subjetiva, una operación de la vida efectuante.

c. Con ello sólo se alcanza lo dado en el mundo de la vida si se va más allá hacía la subjetividad, hacía la formación subjetiva que lo efectúa.

Resumiendo, el sentido del ser ha de buscarse en la vida efectuante, en la subjetividad transcendental que lo realiza, que es la que construye el sentido y la validez del mundo.

$¿ \mathrm{Y}$ el mundo objetivamente verdadero de la ciencia? Este mundo es una formación del grado más alto fundada sobre la experiencia y el pensamiento precientífico, es decir, sobre las operaciones de validez.

Dicho en palabras de Husserl, lo primero en sí no es el ser del mundo en su indudable obviedad. Lo primero en sí es la subjetividad en cuanto esta pone ingenuamente el ser del mundo (mundo de la vida) y después lo racionaliza (mundo de las objetividades científicas) o, lo que es lo mismo, lo objetiviza.

\footnotetext{
43 Ibid. p. 64 (106).

44 Ibid.

45 Ibíd. Pág. 70 (112).
} 
Pero el sentido de esta subjetividad transcendental solo puede ser alcanzado si no se identifica con el hombre, con la subjetividad psicológica. Esto sería un idealismo psicológico. El verdadero subjetivismo transcendental critica la pretensión de legitimidad de la ciencia objetiva como filosofía última, pero al mismo tiempo pretende una cientificidad de tipo nuevo, transcendental.

Husserl va a realizar el análisis del otro polo, el camino hacia el subjetivismo transcendental, en el cógito de Descartes y la intencionalidad (parágrafo 16-20); en la filosofía cartesiana entre empirismo y racionalismo (parágrafos 21-24) y en Kant y la filosofía transcendental (parágrafos 25-28).

Descartes ocupa una posición preeminente en el análisis de Husserl de la otra tendencia hacia el subjetivismo transcendental. Esto por dos motivos. Uno, como es obvio, por los resultados historiográficos ya adquiridos que mostraban a Descartes como fundador de la filosofía moderna (parágrafo 16). Otro, y mucho más decisivo, porque Descartes es, para Husserl, antes que Kant y con mayor radicalidad que el fundador de la filosofía transcendental, el que ha orientado la investigación filosófica en la búsqueda de una fundación absoluta del conocimiento y, por lo tanto, retomando de este modo la exigencia aristotélica de una filosofía primera.

Este conocimiento absolutamente fundado se da en las dos primeras Meditaciones cartesianas (parágrafo 17). El conocimiento filosófico según Descartes se debe basar en un fundamento de conocimiento inmediato y apodíctico que en su evidencia excluya toda duda imaginable. En esta situación es inevitable comenzar por una suerte de epojé escéptica radical, que ponga en cuestión el universo de todas las convicciones que ha tenido hasta el momento y que impide cualquier toma de posición sobre su validez o no. Todo filósofo debe una vez en la vida proceder así.

Esta epojé cartesiana es de una radicalidad inaudita ya que no sólo abarca de todas las ciencias, sino que tampoco acepta la pretendida evidencia de la matemática ni la de la vida precientifica y extracientífica, es decir, «la experiencia sensible y el mundo mismo: como el que para nosotros tiene sentido y ser».

¿Pero cómo es posible para esta epojé demostrar un suelo originario? La respuesta señala, según Husserl, que:

«si excluyo todas las tomas de posición respecto del ser y del no-ser del mundo, si me abstengo de toda validez de ser referida al mundo, sin embargo, dentro de esa epojé, no se excluye toda validez de ser. Yo, el yo que lleva a cabo la epojé, no estoy yo mismo incluido en este ámbito de objetos, más bien -si la efectúo efectiva, radical y universalmente- estoy por principio excluido. Precisamente en esto encuentro la base apodíctica buscada, que excluye absolutamente toda duda posible» ${ }^{46}$.

Es decir, durante la epojé universal «la evidencia absolutamente apodíctica "yo soy" se alza para mí como un mandamiento".

$46 \quad$ Ibíd. pp. 78-79 (120). 
Pero en esta misma evidencia hay incluida mucha diversidad, y esto es de suma importancia, "ego cogito qua cogitata», es decir, incluye todas mis cogitaciones, toda mi vida activa conjunta, "la que experiencia, piensa, valora y demás», solo que al interno de la epojé, como filósofo, lo que estaba ante los ojos como «el mundo», como lo que existe para mí y vale, se ha transformado en fenómeno: "Todas ellas y el mundo mismo se han transformado en mis "ideae" . Esta es una esfera absolutamente apodíctica. Dicho de otra manera, mediante la epojé yo, el yo de la epojé, soy lo único indudable, excluyente por principio de toda posibilidad de duda. Pero Husserl considera, por lo que veremos ahora, que Descartes no llevó a cabo efectivamente el radicalismo originario de su idea (parágrafo 18). La razón es que admirado por este ego recién descubierto en la epojé, se pregunta qué clase de yo es ése, «si es el yo del ser humano, el que es ser humano sensiblemente intuible de la vida en común: luego él desconecta el cuerpo vivido (Leib) — tal y como el mundo sensible (...) y así se determina para Descartes el ego como mens sive animus sive intellectus» ${ }^{47}$.

Pero esto es así porque, según Husserl, Descartes no es suficientemente consecuente con una epojé radical, somete la epojé a una finalidad, la subordina a un fin que es encontrar un camino racional, ya que la sensibilidad puede engañarse, para afirmar como verdadero un en-si existente, el en-si de un mundo de cuerpos (res extensae) puros de la física de Galileo. Este fin, el de solucionar cómo «la configuración racional producida en mi razón (mis propias "clara et distinctae perceptiones") —las de la matemática y de la ciencia matemática de la naturaleza- pueden pretender una validez objetivamente "verdadera", metafísicamente trascendente ${ }^{48}$ (parágrafo 19 ).

El ego o yo que alcanza Descartes, precisamente por esa finalidad que consiste en justificar el mundo de cuerpos extensos de la física de Galileo y de dar eso como verdadero, no es el verdadero ego, es un residuum. Es el alma como residuo de la abstracción previa del cuerpo puro y agregado a él. Pero el ego, el yo, no es un «residuum del mundo sino la posición absolutamente apodíctica que sólo se hace posible por medio de la epojé». En la epojé no hay «alma pura» como tampoco un "puro cuerpo». Es decir, se retorna a un dualismo de nuevo tipo donde la epojé da como lugar a un ego como alma residuo de un cuerpo que impidió ver, durante siglos, si un afuera respecto al ego que podía ser alcanzado por la epojé tenía algún sentido. Por esto, porque todavía no ha llegado a un ego tal y como es mostrado en la epojé "permanece oculto para él que todas esas diferenciaciones, como yo y tú, dentro y fuera, sólo se "constituyen" en el ego absoluto» (parágrafo 19).

Resumiendo:

«Descartes, en su prisa por fundar cuidadosamente el objetivismo y las ciencias exactas como conocimiento absoluto-metafísico, no se planteó la tarea de preguntar sistemáticamente — permaneciendo consecuentemente en

47 Ibíd. pp. 80-81 (121-122).

48 Ibíd. p. 83 (124). 
la epojé- por aquello que en los actos, en las capacidades, es propio del ego puro y lo que produce en ellos como efectuación intencional» ${ }^{49}$.

Este no llevar a cabo radicalmente la epojé por parte de Descartes hace que permanezca latente para él un elemento de la vida egológica que es la «intencionalidad» (parágrafo 20). Otra palabra para decir lo mismo es "cogitatio». Todo acto de la vida egológica, de la vida del yo, es al mismo tiempo acto de algo. Toda conciencia es, al mismo tiempo conciencia de algo.

Después de analizar el comienzo de la filosofía moderna con Descartes y su descubrimiento de la vida egológica (de ese misterio de la subjetividad que el objetivismo no presentía y desde el que se venía hablando en los primeros parágrafos de la crisis y que está ligado a esa nueva ciencia que es la psicología, aunque la psicología no lo puede pensar radicalmente porque, ahora lo entendemos, convierte ese ser psicológico en mente, alma, como opuesto a un cuerpo y lo naturaliza) Husserl, siguiendo la interpretación clásica de la historia de la filosofía moderna, apunta que el pensamiento de Descartes sigue dos líneas (parágrafo 21):

a. la racionalista que es conducida por Malebranche, Spinoza, Leibniz y que a través de la escuela de Wolf llega a Kant, que supone un punto de giro o inflexión: en esta línea "domina la convicción de que puede actualizarse en el método del "mos geometricus", un conocimiento universal, absolutamente fundado, del mundo pensado como un "en-sí" transcendente».

b. El empirismo ingles cuya raíz es Hobbes, su primera elaboración se da con Locke y es retomada por Berkeley y Hume (parágrafo 22-24).

El empirismo juega una función preparatoria fundamental, sea frente al kantismo, sea frente a la propia fenomenología. Esta función consiste en llevar a la luz los límites del incompleto trascendentalismo kantiano.

A partir del ego cogito se desarrolla una filosofía no entendida ya como investigación en torno al «en-sí» del mundo, sino como estudio de los fenómenos psíquicos de la conciencia: esta «ocupada con investigaciones psicológico-internas en el campo del alma de ahora en adelante separada de la corporalidad, así como con las elucidaciones fisiológicas y psicofísicas ${ }^{50}$ (parágrafo 22).

Husserl señala que la contraposición entre estas dos tendencias, racionalismo y empirismo, no está en la referencia a la experiencia que haría el empirismo frente al racionalismo (Apéndice XIV). Esto es así porque la tradición racionalista ha reconocido el rol decisivo que juega en el conocimiento los datos empíricos y, sobre todo, la percepción misma.

Los dos puntos decisivos de contraposición entre racionalismo y empirismo están, según Husserl, en primer lugar, en una tematización por parte de los

$49 \quad$ Ibid. pp. 84 (124-125).

50 Ibid. p. 86 (126). 
empiristas de la experiencia precientifica. Este redescubrimiento viene marcado por su talante antimetafísico que los lleva a criticar el objetivismo racionalista y la tesis de una presunta realidad «en-sí» existente más allá de los sentidos. En segundo lugar un redescubrimiento del cogito cartesiano ya que los principales exponentes del empirismo, empezando por Locke, no tenían una formación científico-matemática, sino que se movían en primer lugar por un interés principal por el mundo histórico-social y, por lo tanto, por un tipo de experiencia difícilmente reconducible al modelo explicativo de las ciencias naturales. Era mucho más fácil modelar ese mundo histórico-social según las operaciones de una ciencia del ego cogito y de sus operaciones.

Por la importancia que tendrá para Kant, el primer pensador, según Husserl que llega a realizar una primera forma de subjetivismo transcendental, veamos algún pequeño trazo del Hume de Husserl.

Hume en su Tratado hace de la experiencia interna la única base del conocimiento, interpreta todas las formaciones de sentido superiores, desde las idealidades matemáticas a las nociones de yo y de causalidad como meras ficciones con una validez convencionalista. A pesar de las críticas que se le puedan hacer, y Husserl las hace, no se puede negar que la filosofía de Hume ha puesto en evidencia el enigma del conocimiento del mundo y su crítica del objetivismo ingenuo constituye la premisa para la plena afirmación de un punto de vista originario en filosofía, de esa subjetividad no empírica sino trascendental buscada por Husserl.

Con Hume viene puesto por primera vez el problema de la formación de los objetos, sea los objetos del mundo precientífico como aquellos de la ciencia a partir de los datos de la sensibilidad:

«Ahora finalmente se podía y debía estar convencido - lo que en estas ciencias había pasado por completo inadvertido-, la vida de la conciencia es vida productiva, bien o mal, productora del sentido del ser; ya como sensiblemente intuido y más aún como científico» ${ }^{51}$.

Si bien viciado de una consideración del ego, del yo, naturalístico-psicologística, el empirismo de Hume comenzó a desarrollar un análisis de las operaciones constitutivas a través de las cuales tiene lugar la formación de los diferentes tipos de objeto.

Pero esta segunda gran parte, entre objetivismo y subjetivismo trascendental, acaba con el estudio del planteamiento de Kant que supone un giro importante en el pensamiento y a él le dedicará Husserl los últimos apartados de esta segunda parte (parágrafos 25-27) y el primero de la siguiente.

Husserl reconoce la importancia epocal que tiene Kant en la historia de la filosofía moderna. Kant señala que Hume le desarraiga del dogmatismo. Pero, ¿es esto del todo cierto? se pregunta Husserl.

Kant permanece atado a un dogmatismo que es el siguiente. Por un lado está la razón pura como sede de proposiciones generales de una doctrina de

${ }^{51} \quad$ Ibid. p. 92 (132). 
reglas. Es decir, de hacer una lógica como doctrina de normas y doctrina de las reglas en la más plena universalidad. Se trataba de desarrollar un universo sistemático de «leyes lógicas» aprióricas (siguiendo el ejemplo de la geometría y la matemática aplicada a la naturaleza de inspiración galileana, respecto de la totalidad teórica de verdades, que como normas para todos los juicios debían ser verdad objetiva). Por otro lado estaba la sensibilidad, la capacidad de experiencia externa e interna. Este dogmatismo consistía en pensar el conocimiento del siguiente modo:

«El sujeto afectado en la experiencia externa desde "afuera", ciertamente se vuelve por su intermedio verdaderamente objeto afectado, pero para conocerla en su verdad necesitaba la razón pura, vale a decir, el sistema de normas, en las que ésta se despliega, como "lógica" para todo verdadero conocimiento del mundo objetivo. Tal es la concepción» ${ }^{52}$.

Entre razón y sensibilidad, para cualquiera que se hubiera asomado a la psicología empirista de Hume, se abría un abismo de incomprensibilidad, es decir, ¿cómo estas verdades de razón podían efectivamente dar respuesta al conocimiento de las cosas? Ya la racionalidad de las matemáticas, desde Hume, se volvía enigmática pero es indudable que su método de idealización, como hemos mostrado, podía resultar inatacable. Pero la ciencia de la naturaleza no era puramente racional, en la medida en que necesitaba la experiencia externa. Lo que en la ciencia de la naturaleza era racional se lo debe a la razón pura y a sus principios, que gracias a ella puede haber experiencia racionalizada. Pero lo que concierne a la sensibilidad produce los datos meramente sensibles justamente como resultado de la afección desde fuera.

A pesar de que la sensibilidad sólo nos da meros datos sensibles nosotros atribuimos ingenuamente esos datos a cosas existentes en si. Pero en realidad lo que tenemos son datos y complejos de datos dados a la sensibilidad que llegan y pasan, «la cosa supuestamente meramente experimentada por vía sensible, no es nada que permanezca a través de este cambio» (parágrafo 25). Por eso, dice Hume, la cosa es una ficción.

Kant no supera del todo el dogmatismo. No lo supera, según Husserl porque sigue atrapado en el esquema anterior ya que «las cosas aparecen pero sólo porque los datos sensibles ya en cierto modo son recogidos por ocultas formas a priori ${ }^{53}$ (el espacio y tiempo de la sensibilidad y las categorías del entendimiento).

Es decir:

«la razón tiene un doble modo de funcionar y de mostrarse: el primer modo es aquel de su auto-despliegue, de la autorrevelación en la libre y pura matematización, en el hacerse de las puras ciencias matemáticas. Todavía esta presupone la formación de la "intuición pura" que todavía pertenece a la sensibilidad. El resultado objetivo de ambas facultades es la matemática pura como teoría. El segundo modo es aquel del constante y secreto obrar de

$52 \quad$ Ibid. p. 95 (135).

53 Ibid. p. 97 (136). 
la razón, la cual racionaliza constantemente y ha racionalizado los datos sensibles. Su resultado objetivo es el mundo de objetos sensiblemente intuidos - el presupuesto empírico de cualquier pensamiento científico, del pensamiento que propone conscientemente ciertas normas a lo empírico del mundo circundante a través de la razón matemática manifiesta. Como el mundo corporal intuido, también aquel de las ciencias naturales (y por lo tanto el mundo dualístico que va conocido científicamente) es en general una formación subjetiva de nuestro intelecto, solo que el material de los datos sensibles proviene de una afección trascendente derivada de las "cosas en sî". Estas últimas son de principio inaccesibles al conocimiento (objetivo-científico) ${ }^{54}$.

Es decir, Kant no ha superado del todo la división entre objetivismo y subjetivismo.

\subsection{La base de la solución a la tensión no resuelta: la dimensión oculta del mundo de la vida (Lebenswelt). Su superación en la subjetividad trascendental (¿Encontrando el camino?)}

Este apartado será más sucinto porque no entra directamente en el objeto de nuestro artículo y debería ser tratado más detenidamente. Lo nombramos esquemáticamente, por lo tanto, para mostrar el término del análisis de Husserl y solo para eso.

Kant no ha superado esa división porque la Crítica a la razón pura no alcanza a mostrar expresamente el presupuesto que está a la base del objetivismo fisicalista y la subjetividad trascendental: «el mundo de la vida obviamente válido» (parágrafo 28). No podía alcanzar esa «dimensión oculta» porque la comprensión del intelecto y la sensibilidad como facultades y como facultades a priori no se lo permiten (algo que analizará en profundidad Zubiri, como veremos). Este «mundo de la vida» es el mundo de la experiencia cotidiana en el cual todos nosotros estamos de modo consciente.

A este mundo de la vida que precede a la supuesta división entre las hipostasiadas facultades de intelecto y sensibilidad se accede a través de una descripción de la originalidad de la posición del sujeto humano en el mundo, si se quiere utilizando una brillante y clásica expresión de Scheler, se accede a través de una descripción adecuada «del puesto del hombre en el cosmos». Nosotros, en términos de esa dimensión del mundo de la vida, somos al mismo tiempo en el mundo «objetos entre objetos» $\mathrm{y}$ «sujetos para esos objetos» $\mathrm{o}$ «sujetos en el mundo». Veamos como lo señala el propio Husserl brevemente:

«En el mundo, nosotros somos objetos entre objetos, dicho en términos del mundo de la vida; vale decir, como siendo aquí y allá con simple certeza de la experiencia (...) Por otra parte, nosotros somos sujetos para ese mundo, vale a decir como sujetos yoicos que lo experiencian, toman en consideración, valoran, que son los únicos para quienes este mundo circundante tiene sentido de ser que, en cada caso, le han otorgado nuestras experiencias, nuestros

$54 \quad$ Ibíd. pp. 97-98 (137). 
pensamientos, nuestras valoraciones etc., y en el modo de validez (de la certeza de ser, de la posibilidad, eventualmente de la apariencia etc.) que nosotros, como sujetos que validan, hemos efectuado actualmente, respectivamente, como adquisiciones habituales poseídas desde antes y que llevamos con nosotros, como valideces de este y aquel contenido que podemos volver a actualizar en voluntad $»^{55}$.

Es decir nosotros somos, antes de dirigirnos a las cosas del mundo como objetos de nuestro conocimiento teórico, «objetos entre objetos» por un lado. Por otro lado, sin que este otro lado o cara cancele el primero, somos sujetos de validez (en su distintitas modalidades: certeza, posibilidad, apariencia etc.); sujetos que constituyen el sentido de los objetos y de nosotros mismos como objetos del mundo (aunque esto último no lo resalte Husserl, se deriva de su propia argumentación).

Este puesto del hombre en el cosmos es abierto desde la realidad corpórea del hombre que tiene esa doble dimensión. Por un lado es un cuerpo-objeto más entre otros cuerpos objetos (Körper), pero por otro lado, sin anular lo anterior, es «cuerpo propio» (Leib). El «cuerpo propio» está a la génesis de la validez, de la constitución de sentido de los objetos del mundo (y correlativamente, aunque no se dice, de mi cuerpo como un cuerpo-objeto más en el mundo). Esto es así porque entre las formas validez, de constitución de sentido del mundo, juega un papel fundamental la experiencia perceptiva individual que se realiza a través de ese «cuerpo propio». En esa constitución tienen una función preferente las «cinestesias», es decir, el «yo me muevo», "yo hago» que unifican todas las otras experiencias perceptivas: ver, tocar, oír, etc. Este mundo de la vida unificado perceptivamente a través del «cuerpo propio» y su «yo hago» (cinestesias) incluye además de la originaria experiencia perceptiva individual las formas intersubjetivas del mundo (Wir-Subjektivität) a través de las cuales se alcanza la construcción de una realidad socialmente compartida. Por último, forman parte del mundo de la vida todas las formas de praxis cultural a través de las cuales se alcanza la constitución de tipos particulares de objetos (por ejemplo: las obras de arte) y la ciencia, que es un ejemplo particular de praxis teórica, de acción teórica.

Pero esto ya muestra lo que unifica el mundo de la vida, el secreto oculto del mundo de la vida: la subjetividad. Como decía Husserl al principio: el «misterio de la subjetividad». El mundo de la vida, y el mundo de la realidad socialmente compartida (dentro del cual entran las teorías científicas) es una "formación de sentido» que se constituye a partir de un conjunto de actos individuales y colectivos. Llevar esto a su explicitación rigurosa será tarea de la fenomenología transcendental.

Para terminar, esa subjetividad que está a la base del mundo de la vida como de sus objetivaciones posteriores no es una subjetividad empírica, sino una subjetividad pura. Señalémoslo brevemente. La subjetividad o el yo que es el

$55 \quad$ Ibid. p. 107 (146-147). 
misterio del mundo de la vida en todas sus dimensiones no es la subjetividad como «yo real en el mundo». Esa subjetividad del yo real, que no es propiamente una cosa como señalamos antes, está en el mismo plano de las cosas reales. Esa subjetividad empírica o yo real no garantizaría, y de eso se trata en último término, una ciencia única de verdades universales. Es la subjetividad pura o el yo puro que permite:

«comprender que el mundo existente permanente para nosotros en el cambio fluyente de los modos de darse, es una adquisición espiritual universal como devenido, y que al mismo tiempo sigue deviniendo como unidad de una forma espiritual, como una configuración de sentido, como configuración de una subjetividad universal última-fundante» ${ }^{56}$.

\section{LA CRISIS DE LA RAZÓN EN ZUBIRI}

2.1. La génesis de la crisis de la razón en Zubiri: la entificación de la realidad (El ovillo de Ariadna)

La génesis de la crisis de la razón para Zubiri está en la logificación de la inteligencia y en la entificación de la realidad. Lo primero que hay que comprender es cómo se da esa logificación y entificación.

Para Zubiri, como para Husserl, la crisis de la razón tiene su manifestación plena en la filosofía moderna. Por filosofía moderna entiende Zubiri aquella que va desde el siglo xvi hasta el comienzo del siglo xx (excluyendo la contemporánea).

Se va a enfrentar esta filosofía a lo real, pero entendiendo lo real, por ahora, en el sentido más obvio y trivial de las cosas existentes, es decir sin distinguir entre real como existente frente a lo no existente, sino real como «el conjunto (...), el sistema de las cosas concretamente existentes ${ }^{57}$. Entendido de este modo lo real, se trata de preguntarse cuál es la forma sistemática en la que la filosofía moderna concibe lo real. Pero hay que entender correctamente «forma sistemática». En toda filosofía hay que distinguir dos momentos o planos: uno, el plano de las grandes ideas y otro, el plano el modo de acercarse con esas ideas a lo real.

Esta investigación de Zubiri se realizará en dos momentos: primero buscara las ideas fundamentales de la filosofía moderna y, después, como están entreveradas las mismas de forma sistemática para aprehender de modo concreto lo real. Primero Zubiri enumera esos grandes conceptos: espacio, tiempo, ser y conciencia. Toda filosofía se apoya en las cosas más elementales. Aquí cosa

$56 \quad$ Ibid. p. 115 (155).

57 ZubiRI, X. (2009). Cinco lecciones de filosofía. Madrid: Alianza Editorial. Fundación Xavier Zubiri. Cito la conferencia que lleva por título: El sistema de lo real en la filosofía moderna. pp.: 253-306. A partir de ahora cito el libro como $C L F$, pp. 253-254. 
tiene el sentido más general posible como cuando en alemán se dice Sache o Ding. Estas cosas están en algún sitito, es decir, se hallan en el espacio y por lo tanto nos encontramos con la idea de espacio. Ocurren, acontecen alguna vez. Es la idea de tiempo. Todas las cosas se nos muestran como «siendo» aquello que son, es decir, nos encontramos con la idea de ser. Este ser lo que son de las cosas lo son para una conciencia: aparece la idea de conciencia.

Empecemos por el análisis de estas grandes ideas y después veremos cómo se acerca la filosofía moderna, a través de ellas, a la realidad.

El problema es cómo tratar esos conceptos para que nos muestren el modo de acercarse a la realidad propio de la filosofía moderna. Si nos movemos solamente en el plano de la descripción de las ideas aparecerán diferencias tan grandes en los autores modernos que harían imposible hablar de un modo común de acercarse a la realidad de toda la filosofía moderna. Por ejemplo, si tomamos el espacio para Kant es una intuición pura a priori y para Leibniz un concepto a posteriori, luego nada común les une. Pero si nos movemos no en la descripción de ideas (contenidos), sino en su forma de acercarse a lo real que las ideas apuntan puede que si haya algo común. Por ejemplo que ambos autores (habrá que mostrarlo) hayan "concebido que el espacio tiene una entidad propia ${ }^{58}$. Aquí, en este plano, es donde se juega la especificidad de ese periodo que comienza en el siglo xvi y termina a principios del xx y llamamos filosofía moderna. A lo mejor lo propio de la misma es que espacio, tiempo, ser y conciencia «los ha concebido o los ha tomado como si fueran realidades sustantivas ${ }^{59}$. Esto es lo que Zubiri ha llamado entificación y es más radical que lo que Husserl ha llamado objetivismo fisicalista. ¿Pero qué hay detrás de esa entificación? En este proceso de entificación el pensamiento cristiano ha tenido, para Zubiri a diferencia de Husserl, una importancia decisiva. Veamos brevemente esas ideas.

Empecemos con el espacio. Es obvio o incluso trivial decir que todas las realidades, por lo menos las que no son puramente mentales o espirituales, ocupan un espacio. Un «dónde». Pero en la historia del pensamiento ha tenido lugar una gran trasformación en la forma de pensar y vivir este «dónde» debido al cristianismo que afirma del Padre Eterno (la primera persona de la trinidad) que «está en los cielos». Cielo no tiene un sentido espacial sino que expresó la inmensidad divina, es decir, su carácter de no mensurable, su carácter de no espacialidad. Expresa la idea de que está «en todo el espacio, en todas las cosas sin estar circunscrita a ninguna, tampoco definitivamente recluso en ninguna de ellas ni en el conjunto del mismo mundo ${ }^{60}$.

Esta idea tiene, según Zubiri, unas virtualidades filosóficas de gran calado. $\mathrm{El}$ «dónde» ya no expresa la idea trivial de «en alguna parte», sino que es «esa especie de gran océano, de gran piélago en el que la divinidad existe como

\footnotetext{
$58 \quad$ Ibíd. p. 259.

59 Ibid.

$60 \quad$ Ibíd. p. 260.
} 
inmensa... ¿dónde? En el mundo entero, en el mundo que ha creado» ${ }^{61}$. El lugar ya no es mero espacio físico (expresado con «en alguna parte»), sino el lugar de las cosas en el conjunto de la creación. El espacio es un gran piélago divino, el conjunto de la creación a la que Dios da el ser.

Si prescindimos en esta idea del espacio de su raíz teológica y nos quedamos con lo que tiene exclusivamente de momento estructural de mundo, entonces resta que: «la inmensidad de Dios se torna en una cosa distinta, se torna en el receptáculo espacial y vacío en el que colocamos todas las cosas» ${ }^{62}$. El dónde de las cosas no es algo en el piélago divino, sino «un determinado punto en el espacio».

Esta idea, de matriz teológica, pasó a la filosofía y a la ciencia moderna. En la filosofía podemos ilustrar esto con un texto de Gassendi (un contemporáneo de Descartes) citado por Zubiri:

«Aunque efectivamente no existiesen cuerpos, sin embargo sobreviviría el espacio constante y el tiempo fluente. Y por esto parece que el lugar y el tiempo no penden de los cuerpos y que, por consiguiente, no son accidentes de los cuerpos... De donde resulta que el ente, tomado en su máxima generalidad, no se divide adecuadamente en sustancias y accidentes y de aquí resulta que el espacio y el tiempo tienen entidad real y verdadera ${ }^{63}$.

En la ciencia, medio siglo después, recuerda Zubiri con un texto de Newton al comienzo de su mecánica: «El espacio es absoluto por su propia naturaleza sin relación ninguna a nada externo a él. Permanece igual a sí mismo y sin movimiento. El espacio relativo es la medida de este espacio absoluto por medio de cuerpos que se mueven en él» ${ }^{64}$. En Newton pervive la matriz teológica de esa idea del espacio hasta el punto de que habla de él como un sensorium Dei. Un siglo más tarde Euler, el gran matemático parece oponerse a ese residuo teológico del espacio como una sustancia. Pero, según Zubiri, sólo es una apariencia. Veamos el motivo: «No afirmamos en manera alguna que exista ese espacio infinito (...). Postulamos solamente que quien quiere contemplar el movimiento y el reposo absolutos tiene forzosamente que tener esa representación del espacio absoluto» ${ }^{65}$. La diferencia, de ahí la apariencia, está en un pequeño matiz según Zubiri:

«Newton todavía vive de la pervivencia del pensamiento teológico medieval y concibe que esa entidad propia del espacio es la de una sustancia. Contra esto se revuelve y con razón Euler, quien representa exactamente lo que decía Gassendi: que no son sustancias, pero sin embargo tienen una cierta entidad. Euler, como matemático, no tiene por qué entrar en la cuestión » ${ }^{66}$.

\footnotetext{
61 Ibid.

62 Ibíd. p. 262.

63 Ibid.

$64 \quad$ Ibid. p. 263.

65 Ibid. p. 264.

${ }_{66}$ Ibid. p. 265.
} 
Ese espacio absoluto, sea concebido en forma de sustancia o teniendo una cierta entidad, tiene una estructura determinada: «Ese espacio vacío, ese receptáculo de las cosas, es un espacio euclidiano; tiene tres dimensiones ${ }^{67}$.

El segundo concepto es el tiempo. Este responde a la pregunta trivial: ¿Cuándo acontece una cosa? Es algo paralelo a la pregunta sobre el «dónde» del espacio. La respuesta parece igual de sencilla: cuando llueva, cuando salga el sol..., señala Zubiri.

Pero para entender lo que entraña esta sencilla respuesta hay que mirar otra vez a las raíces teológicas ${ }^{68}$ del concepto de tiempo que subyace a la respuesta.

Dios es eterno y esto se ha entendido como algo que no tiene principio ni fin. Este carácter eterno de Dios supone «que se encuentra presente en todos los tiempos de su creación y, entonces, el tiempo, el "cuándo" ocurre cada cosa, es justamente el plazo que la divinidad le ha asignado, es esa especie de despliegue temporal en que consiste la dinámica de la creación» ${ }^{69}$. Dios, sin principio ni fin, se encuentra presente en todos los tiempos de su creación y el tiempo, el cuándo, es el despliegue tasado por la divinidad de algo al interno de su eternidad.

Volviendo a los primeros pensadores cristianos este carácter (el despliegue de algo tasado, con un límite, al interno de la eternidad de Dios) se traduce con el término eón. Dios, por su carácter de eternidad está por encima del eón: el eón como duración no pertenece sino al cosmos. Eternidad y duración (eón) están íntimamente relacionados y, al mismo tiempo, son muy distintos. Dios es eterno y las cosas tienen una duración (eón). Eón se reservó para la duración de las cosas. Por lo tanto, no para una duración vacía, sino para el plazo en el que se despliega el ser de las cosas. Entendiendo por el ser de las cosas también sus operaciones dirigidas a alcanzar el desarrollo o plenitud de ese ser, su distensión. Mientras que de Dios que no tiene ser, sino que es el ser, se habló en término de aionios (eternidad).

Si dejamos de lado el origen de este concepto, Dios y la creación, y nos quedamos con el resultado nos encontramos con lo siguiente: «el tiempo se nos ha convertido en esa especie de línea temporal indefinida en la cual se van inscribiendo todos los acontecimientos que en el mundo acaecen ${ }^{70}$.

La idea de «cuándo» sufre una variación. Si corrientemente significa «cuando» salga el sol... Ahora «cuándo va a significar en qué punto de la línea temporal está inscrito el acontecimiento ${ }^{71}$.

Desde este punto de vista el tiempo es un espacio, una especie de receptáculo fluente: la línea temporal. Es lo que Newton llamó tiempo absoluto: «El

67 Ibíd. p. 266.

68 Para las raíces teológicas del concepto tiempo es necesario consultar el Theologisches Wörtebuch zum Neuen Testament. La edición de Zubiri era la traducción italiana. KitTeL, G. - Friedrich, G., (1965) Grande lessico del Nuovo Testamento. Brescia: Paideia.

69 ZuBiri, X., $C L F$. p. 268

$70 \quad$ Ibíd. p. 269.

71 Ibid. 
tiempo absoluto, verdadero y matemático, fluye en sí mismo y por su propia naturaleza, sin relación externa a nada. Y con otro nombre decimos duración » ${ }^{72}$. El «cuándo» tiempo relativo (aparente y vulgar) «es una medida de cualquier duración - hora, día, mes- de este tiempo absoluto. De ahí que todo tiempo aparezca como fragmento de un tiempo único» ${ }^{73}$. ¿Es esto así? Choca con varias dificultades.

Primero porque es difícil concebir que el tiempo, como el espacio, tenga unas propiedades independientes de los cuerpos que transcurren temporalmente. Zubiri pone el ejemplo del tiempo astronómico y el tiempo de mi vida mental:

«¿cómo decir que son fragmentos de un solo tiempo? Es cierto que puedo decir que he estado meditando una hora, pero eso no significa que mi vida mental tenga la estructura métrica de una hora, sino que lo que he estado haciendo durante una hora del tiempo solar es meditar; esto es completamente distinto que decir que la hora, métricamente tomada, es un ingrediente formal de mi propia vida mental. ¿Cómo se va a pretender, entonces, que todos los tiempos sean fragmentos de un tiempo único?» ${ }^{74}$.

Segundo. El tiempo, como el espacio, nos aparece como algo que está dotado de entidad propia y, también como el espacio, es anterior a las cosas. Toda cosa para ser necesita ser en algún sitio del espacio y ocurrir en algún momento en el tiempo, pero el espacio y el tiempo ya están allí: «el espacio quiescente e inmóvil con sus estructuras euclidianas, el tiempo como una línea fluente que transcurre inflexible de un pasado a un futuro» ${ }^{75}$. Con una diferencia importante: el tiempo es más universal que el espacio: «sea o no el tiempo de mi vida mental un fragmento del tiempo único, lo cierto es que mi vida mental está en el tiempo, pero no está en el espacio; la vida mental no se puede someter a las ecuaciones de Newton, como se puede someter la realidad física que me circunda», pero ambas transcurren en el tiempo.

Si tomamos ahora juntamente espacio y tiempo veremos que son concebidos como teniendo una entidad sustantiva anterior a toda sustancia y accidente: «es la estructura fluente de un cosmos, cuya estructura formal es el espacio euclidiano» ${ }^{76}$. Resumiendo: Newton dirá hasta la saciedad «que el espacio y el tiempo son independientes de las cosas, pero, además, son independientes entre sí (...). Tan independientes que hay cosas que no están en el espacio, pero todas están en el tiempo» ${ }^{77}$.

Lo curioso es que ha sido la propia ciencia positiva la que ha mostrado la insostenibilidad de esta concepción del espacio y el tiempo. Fijémonos en un hecho muy concreto: la luz. La luz pone de manifiesto a la física la necesidad

\footnotetext{
72 Ibid. 270.

Ibíd.

Ibid. pp. 270-271.

Ibid. p. 271.

Ibíd.

Ibid. pp. 271-272.
} 
de concebir que el espacio y el tiempo reciben propiedades de las cosas y que, además, espacio y tiempo no son independientes entre sí. El hecho de que la luz tenga una velocidad constante hace que su velocidad no pueda ser sumada con ninguna otra velocidad del universo. Es decir, la velocidad, entendida como medida de un tiempo es algo peculiar de esa «cosa» llamada luz.

El tercer concepto es el de ser. De cualquier cosa se puede decir que es lo que es y desde el comienzo de la filosofía en Europa se ha pensado sobre ello (Parménides). Esta cuestión de ser ha venido rodando desde la filosofía griega hasta la Edad Media. Pero hay que matizar esto (otra vez aparece el problema de la sustantivación): lo que se pretendió era ir a las cosas (yo diría al ser de las cosas) no al ser: «Atribuir al pensamiento griego una especulación del ser en tanto que distinto de las cosas sería un gigantesco anacronismo histórico, anacronismo que se ha cometido» ${ }^{78}$.

Que las cosas «son», que una cosa «es», ese es el problema para Zubiri, no el ser en cuanto algo diferente de las cosas.

Aquí también influyó la teología cristiana desde el concepto de la creación:

«la creación consiste en que las cosas son creadas por Dios desde la nada. Cuando no había cosas, la cosa "no es" y, después de la creación, la cosa "es" (...) Con lo cual se quiere decir que Dios, que otorga el ser, no es una realidad que recibe el ser, sino que es el ser mismo subsistente ${ }^{79}$.

Esto es, según Zubiri, una interpretación metafísica entre otras posibles de la idea de Dios (y de la creación, añadimos nosotros).

Santo Tomás, desde esta experiencia, dice que «toda cosa creada, participa, por así decirlo, de la naturaleza del ser». Es decir, el ser aparece como «una especie de piélago en el que Dios se proyecta ad extra y fuera de sí mismo ${ }^{80}$. Si ahora, como pasó con el espacio y el tiempo, cortamos la vinculación de ese piélago con Dios lo que nos queda es una sustantivación del ser del cual las cosas son contracciones suyas (interpretación de Aristóteles) concreciones suyas (interpretación de Platón) o, una tercera posibilidad, el ser sería lo que primariamente tendría sustantividad (interpretación de la filosofía moderna por debajo de sus diferencias entre interpretaciones empiristas, racionalistas o idealistas). Es decir, la sustantivación de la idea de ser.

La estructura de este ser sustantivado es el principio de contradicción entendido no solamente de forma lógica sino ontológica:

«El principio de contradicción no es un principio del decir, sino la estructura interna del ser, de tal manera que algo que fuese contradictorio sería un contra-ser, a menos que se estimara que precisamente ese "contra" fuese un momento dinámico interno a la estructura misma del ser, como sucede en la filosofía de Hegel» ${ }^{81}$.

78 Ibíd. p. 273. Zubiri está pensando, evidentemente en Heidegger.

79 Ibid.

$80 \quad$ Ibíd. pp. 273-274.

$81 \quad$ Ibid. p. 275. 
Veamos cómo se llega ahí. Para Leibniz (como para sus discípulos Wolff y Baumgarten) la estructura del ser es el principio de no-contradicción, es decir, que ser (einai) y no ser (mē einai) no pueden ser verdad a la vez. Esto ya lo decía Aristóteles, pero mientras para este último el principio era un principio de contra-dicción, un principio del decir mismo, para Leibniz y sus discípulos era un principio de "contra-ser», un principio de las cosas mismas. Por este principio:

«La nada es el no-ser y el no-ser es la contradicción; contradecirse (en el sentido aristotélico) es no decir nada porque el ser es formal y constitutivamente incontradicción hasta tal punto, nos dirá Wolff, de que un mundo que no estuviese regido por esa contradicción interna no sería un mundo real (non esset mundus realis), sino un mundo fabuloso (mundus fabulosus)» ${ }^{82}$.

El ser es sustantivado y su estructura es la no-contradicción entendida de modo ontológico o el «no contra-ser».

Pero que el ser tenga la estructura del «no contra-ser» supone previamente que el ser se ha sustantivado. No importa que el ser sea concepto (más tarde Zubiri mostrará porque es así) y que este sea lo dado en percepción (empirismo), lo seguro (Descartes) o de una evidencia irrefragable por su no contradicción (Leibniz), una posición del espíritu (Kant). Pues todo eso lo percibido, lo claro y distinto, lo incontradictorio, lo puesto es «el ser, tomado así en singular y en abstracto, no las cosas en tanto que son. Se trata pues de la sustantivación misma de la idea de ser» ${ }^{83}$.

El ser tiene sustantividad propia y aparece como la tercera de las sustantivaciones de la filosofía moderna.

La cuarta sustantivación ha sido la de la conciencia. Desde los tiempos de Platón y Aristóteles se ha dicho que «el hombre por su inteligencia sabe lo que las cosas son ${ }^{84}$. Se ha definido al hombre como «zoon logon ejón», que se ha traducido habitualmente por «animal racional», pero que sería más preciso traducirlo por «animal que tiene logos o razón».

El cristianismo introdujo la idea de que el hombre es una imagen de Dios. Esto supone que se nos diga qué se entiende por Dios y dónde está la semejanza. La teología, partiendo de que había dicho que el hombre tiene logos, y de que Dios (según el grandioso prólogo de Jn,1) se revela a sí mismo en el Verbo encarnado, en el logos, puso en conexión el logos del hombre (el logos de la filosofía griega) con el logos de Dios (el logos de la revelación cristiana): «naturalmente, la semejanza con Dios reside en que el hombre, todo lo finito que se quiera, tiene alguna semejanza con el logos divino ${ }^{85}$. De ahí que el hombre como imagen de Dios participa de alguna manera en la naturaleza divina de una doble manera.

$82 \quad$ Ibíd. pp. 274-275.

83 Ibid. p. 275.

$84 \quad$ Ibid. p. 277.

85 Ibid. p. 278. 
Por una lado tiene una dimensión que podríamos llamar (Zubiri no lo hace) creatural y como criatura (creación) de Dios «ha comenzado a existir alguna vez en la creación, no ha existido siempre y alguna vez, mucho antes que las cosas físicas, dejará de existir porque es un efecto de Dios como los demás» ${ }^{86}$. Pero además es una criatura con logos, con razón. Por el logos el hombre se parece a Dios no solo por una relación extrínseca de causa y efecto, sino por una relación más interna, por una semejanza más interna:

«Con ello el hombre pierde su carácter de ser sólo una criatura más perdida en el universo y se convierte en algo llamado a ser el lugar natural donde se aprehende y se constituye el ser de cuanto es: el hombre como envolvente del universo entero justamente por su razón ${ }^{87}$.

Si una vez más, como Zubiri ha hecho en los otros casos, desvinculamos esta visión de sus raíces teológicas nos quedamos

"con que el hombre se enfrenta con el resto de las cosas, las cuales le son presentes a él, no solamente es una "ciencia", sino que en esta idea que tiene el hombre de las cosas "con-sabe", un poco como Dios, su propia realidad: tiene "ciencia" y "conciencia" ${ }^{88}$.

Es decir el hombre, desvinculado de sus raíces teológicas es el lugar donde se aprehende y se constituye el ser de cuanto es (el envolvente del universo entero), es el lugar de la ciencia y, además, es el lugar dónde el hombre al mismo tiempo que aprehende el ser «con-sabe» su propio ser: «conciencia». Es lugar de constitución o aprehensión del ser (Ciencia) y, al mismo tiempo, de «consaber» su ser: "conciencia». Esto es el saber absoluto (resultado, para ambos Zubiri, del pensamiento cristiano desligándolo de sus raíces). La conciencia de este modo es sustantivada como autoconocimiento y constitución del ser.

Con esto culminan las cuatro grandes sustantivaciones de la filosofía moderna: «el espacio como aquello en dónde los cuerpos están, el tiempo como aquello cuando los tiempos ocurren, el ser como aquello en lo que consiste una cosa, y la conciencia como aquello para lo cual las cosas reduplicativa y formalmente son ${ }^{89}$.

Estas cuatro sustantivaciones tienen una precisa unidad intrínseca y es lo que hay que ver ahora para comprender el sistema de la filosofía moderna.

\subsection{La unidad sistemática de estas cuatro sustantivaciones en la filosofía} moderna (En el corazón del laberinto: sacrificando al monstruo)

Esto lo va a desarrollar Zubiri en dos partes, En primer lugar mostrando esa interna unidad y en segundo lugar en enfrentándose al problema que esa unidad plantea.

$\begin{array}{ll}{ }_{86}^{86} & \text { Ibid. } \\ { }_{87} & \text { Ibíd. } \\ { }_{88} & \text { Ibid. p. 279. } \\ { }_{89} & \text { Ibid. p. 280. }\end{array}$


Zubiri, para ver esa unidad, empieza por lo que para él es el concepto más vago, el de ser. Pero veámoslo. El verbo ser puede tener el sentido de infinitivo, de un verbo, pero también puede tener el sentido de un sustantivo: el «ser». Es el que le interesa a Zubiri.

¿Qué es eso del ser sustantivado? La filosofía moderna, que es de lo que aquí se trata, ha partido siempre de que eso de que sea el «ser» es algo "por sí mismo inexorable», es decir, algo que no se puede evitar. Así Kant en el opúsculo citado Der einzig mögliche Beweisgrund zu einer Demonstration des Daseins Gottes nos dice que el único punto de partida posible es demostrar que algo de lo que es, es Dios; no que Dios es, sino que algo de lo que ya es, es Dios; bien entendido que es absolutamente imposible que no haya nada. El «ser» es inexorable, es algo inevitable. Pero ¿de dónde sale esta inevitabilidad?

No se trata de una constatación, por ejemplo porque yo pienso (aunque no lo cita Zubiri es el caso de Descartes). No explica Zubiri porque esto no sería pertinente para el problema del «ser», pero me parece que es claro que a lo sumo el yo pienso llevaría al ser del pensante, pero no al «ser» sustantivado. ¿De dónde sale entonces esta inevitabilidad? Del principio de «no contradicción» aplicado ontológicamente:

«el ser es algo porque es imposible porque está caracterizado por ser lono-imposible, porque es imposible que no sea. Ahora bien, se nos dice que esta imposibilidad es la incontradicción intrínseca que constituye el ser; de ahí que todo el racionalismo, que se basa precisamente en la idea del ser como opuesta al no-ser, el no ser es justamente lo contradictorio» ${ }^{90}$.

Es decir, el ser es lo no-contradictorio, lo posible y por lo tanto lo que es imposible (necesidad) que no sea. Es decir, el ser es surge del principio lógico de la no contradicción. Aquí entificación o sustantivación de las grandes ideas del pensamiento moderno y logificación coinciden.

Desde aquí podemos dar una definición del «ser» sustantivado:

«esa especie de magno piélago, necesario por un lado, imposible de no-ser por otro e intrínsecamente dominado por la incontradicción. Todas las demás cosas son concreciones de ese ser (si se emplea el lenguaje de Platón) o determinaciones y contracciones de ese ser (sí se recurre al lenguaje de Aristóteles y de la escolástica)» ${ }^{91}$.

Todas parten de esta sustantividad del ser. El ser no solo está regido por la inexorable necesidad de la incontradicción, sino que «desde sí mismo y en tanto que ser, es espacial y temporal». El espacio y el tiempo son ámbitos del ser. El espacio es el ámbito del ser corpóreo y por ello el espacio es anterior a las cosas. El tiempo, que es ámbito más universal que el espacio, porque «si no toda realidad está en el espacio (los sentimientos, los pensamientos), está inexorablemente en el tiempo como lo está el universo físico». El espacio y el

${ }_{90} \quad$ Ibíd. p. 282.

91 Ibíd. 
tiempo son ámbitos del ser. El ser en su inexorabilidad, transcurre en el ámbito del espacio-tiempo, si es corpóreo, o en el ámbito del tiempo, si no es corpóreo.

Además del espacio y el tiempo como ámbitos del ser tenemos la conciencia. Desde Descartes, afirma Zubiri, se nos dice que la conciencia tiene sustantividad es un "cogito me cogitare». Se trata de ver qué es esa conciencia desde su unidad intrínseca con el ser, el tiempo y el espacio. La afirmación de Zubiri es que esa conciencia es representación (Vorstellung) de las cosas. ¿Qué es esta representación? Es la unidad sistemática del «ser con todas sus dimensiones espacio-temporales y el acto subjetivo de darse cuenta» ${ }^{92}$. De ahí que el problema básico de la filosofía moderna sea el de una teoría de la representación.

¿Es verdad que esto es la estructura de lo real? En cuanto nos enfrentamos a estos conceptos sistemáticamente unidos surge una cuestión fundamental en función de que el problema básico de la filosofía moderna sea una teoría de la representación y es que la representación es representación de una conciencia es decir, la estructura de lo real moderna recae sobre la conciencia (inteligencia) vista en su función representativa.

El problema es si realmente la conciencia, tomada subjetivamente, no es un acto, es el carácter que tienen ciertos actos. El carácter de «darse cuenta». Pero el acto es fundante respecto al «darse cuenta», respecto a la conciencia. La conciencia es el carácter de ciertos actos, no la que los ejecuta. Pero ¿actos de qué? De la inteligencia no tomada como facultad, sino como actividad:

«Digo que eso que constituye la conciencia es sólo carácter de algunos actos intelectivos porque tampoco todos los actos intelectivos del hombre están caracterizados por la conciencia; en efecto, basta pensar en la larga lista de lo que es inconsciente, de lo que es preconsciente, de lo que es postconsciente, de lo que es subconsciente... $\rangle^{93}$.

Por lo tanto la conciencia no puede sustantivarse. Esta será la gran crítica que hará Zubiri a Husserl: la de entificar la conciencia. Pero admitido esto se podría afirmar que la conciencia, el «darse cuenta» sería el carácter supremo del hombre frente al ser.

En la filosofía moderna ese «darse cuenta» es un «darse cuenta» representacional. Entonces la representación en la conciencia sería forma suprema de enfrentarse el hombre al ser. ¿Qué es representación? Como indica el vocablo es «volver a presentar algo que, por tanto, ya estaba presente»" ${ }^{94}$ Es decir, la representación es un acto segundo que ya presupone un acto primero, que es la presentación. El problema está en saber dónde se hacen presentes las cosas a la inteligencia para que esta después se las represente. La filosofía ha solido responder a esta cuestión diciendo que «la presentación de las cosas no es obra de la inteligencia misma, sino de los sentidos», del sentir.

$92 \quad$ Ibíd. p. 285.

93 Ibíd. p. 286.

$94 \quad$ Ibíd. p. 287. 
Resumiendo: la filosofía moderna ha supuesto una gigantesca entificación del ser, de sus ámbitos del espacio y el tiempo, porque ha concebido la inteligencia (conciencia) como una facultad representativa, como envolvente del universo entero, unificadora, de lo sentido a través de sus conceptos y, sobre todo, a través del principio de no-contradicción como contra-ser (esto será objeto de nuestra segunda meditación).

Pero por entificación no entiende exactamente lo mismo que Husserl por objetivismo fisicalista. Zubiri entiende que el ente, el ser, sus ámbitos (el espacio y el tiempo) han desplazado en la filosofía a la realidad (como momento del acto intelectivo). Por logificación, ahora lo desarrollaremos brevemente, entiende Zubiri que esta entificación tiene como correlato la inteligencia como facultad de envolver, constituir y en caso extremo construir el universo entero: la subjetividad trascendental de Husserl y esa es su crítica más profunda al fundador de la fenomenología y, por eso mismo considera que Husserl no ha escapado del todo a la crisis de la razón que intenta superar.

\subsection{La raíz de la entificación y logificación en la separación entre el inteligir y sentir. Su superación en la aprehensión primordial de la realidad (¿Encontrando el camino?)}

La raíz común de esta entificación y logificación de la realidad (entificación en cuanto el ser, sus ámbitos, el espacio y el tiempo, se conciben con entes, como cosas objetivas y logificación en cuanto esas cosas objetivas son «concebidas» por la inteligencia) está en la contraposición entre sentir e inteligir y no, como Husserl, en la tensión no resuelta entre objetivismo fisicalista y subjetividad transcendental. Por lo tanto el problema no se sitúa en el renacimiento y en la ciencia galileana, sino desde los orígenes mismos de la filosofía donde ya se señala que:

«una cosa es (...) sentir, otra inteligir. Este enfoque del problema de la inteligencia contiene en el fondo la afirmación: inteligir es posterior a sentir, y esta posterioridad es una oposición. Esta fue la tesis inicial de la filosofía desde Parménides, que ha venido gravitando imperturbablemente, con mil variantes, sobre todo la filosofía europea $»^{95}$.

Es decir, desde los orígenes se «ha partido de contraponer "inteligir" a "sentir". Intelección y sensación serían dos formas opuestas», más precisamente, dos formas opuestas en cuanto dos actos de dos facultades esencialmente diferentes. Así lo entendió la filosofía griega y medieval. Si, como advierte $\mathrm{Zu}-$ biri, empleamos el término "cosa» en su sentido más general y trivial como sinónimo de algo (Ding en alemán) habría que decir que «la filosofía griega y

95 ZuBIRI, X. (2013) Inteligencia y realidad. Madrid. Alianza Editorial. Fundación Zubiri. pp. 11-12. A partir de ahora lo citaré como IRE. 
medieval ha considerado inteligir y sentir como actos de dos facultades, determinada cada una de ellas por la acción de las cosas $»^{96}$.

El primer problema de esta afirmación es que enseguida se abandona o se va más allá del acto: va, en el sentido literal, allende el acto (hace metafísica en el sentido de ejercer una transcendencia del ente hacia la entidad como otro ente). Es lo que se expresa con el «de». La filosofía griega y medieval transcienden el acto, viéndolo como «acto de» facultades y la filosofía moderna transciende el acto viéndolo como «acto de» conciencia, modo de la conciencia (por esta razón profunda es por la que Zubiri entiende que la conciencia es sustantividad en la filosofía moderna). Veamos estos dos modos de ir allende el acto, de convertir el acto en "acto de» y transcenderlo hacia una sustantivación (metafísica) o bien de facultades o bien de conciencia.

En la filosofía griega y medieval se hace metafísica de la inteligencia porque se va más allá de los actos intelectivos y sensitivos a unas supuestas facultades que sostendrían esos actos (sin hacernos por ahora problema de si son dos actos o un acto único con momentos diferentes). Se trata pues de analizar «los actos mismos. Son hechos bien constatables, y debemos tomarlos en y por sí mismos y no desde una teoría de cualquier orden que fuere ${ }^{97}$. No se trata de hacer metafísica de la inteligencia.

En la filosofía moderna el hacía, el «de», de ese transcender el acto se da en otra dirección, en la de la conciencia. Inteligir y sentir «serían dos modos de darse cuenta, es decir, dos modos de conciencia» ${ }^{98}$. Esta es la dirección que va desde Descartes a Husserl. La fenomenología no sería un análisis del acto intelectivo, sino una metafísica de la conciencia y de los actos de la misma ${ }^{99}$ en cuanto se desliza del acto al modo de darse cuenta de una conciencia.

La dirección es distinta, pero es también una dirección metafísica en el sentido de superar, transcender, ir allende el acto mismo, para sustantivar el «darse cuenta» como conciencia. Esto implica según Zubiri dos cosas:

1. Que la conciencia ejecuta actos.

2. Que lo formalmente constitutivo de la conciencia es el «darse cuenta».

Respecto a lo primero, que la conciencia ejecute actos, supone un sustantivar la conciencia. El único hecho que tenemos como indubitable no es el «darse cuenta»o «la conciencia», «sino los actos conscientes de índole muy diversa». Aquí Zubiri es muy tajante subrayando que esto también es un modo de transcendencia metafísico:

$96 \quad$ Ibid. p. 19.

97 Ibid. p. 20.

98 Ibid. pp. 20-21.

99 Gracia, D. (2007), Voluntad de verdad. Madrid. Triacastela. p. 104. Diego Gracia, probablemente el mayor conocedor del pensamiento filosófico de Zubiri, califica de metafísico el planteamiento de Husserl, aunque Zubiri no lo haga explícitamente y se limite a decir teórico. Me alegra coincidir con él como signo de que no he errado mucho. 
«So pretexto de no apelar a una "facultad", se sustantivó el carácter de algunos actos nuestros, y se convirtieron entonces estos actos en actos de una especie de "superfacultad" que sería la conciencia»"

Respecto a lo segundo, no es verdad que lo constitutivo del acto intelectivo sea «el darse cuenta», el darse cuenta es siempre un darse cuenta de algo que está presente a la conciencia. Y justamente ese «estar presente no está determinado por el darse cuenta. La cosa no está presente porque me doy cuenta, sino que me doy cuenta porque está ya presente» ${ }^{101}$ (es claro que es un estar presente en intelección).

Una vez señalado el hecho de que hay que ir al acto intelectivo mismo y no transcenderlo en orden a una sustantivacion Zubiri pasa a preguntarse cuál es la índole o el carácter del acto intelectivo mismo. Citemos el texto mismo que es importante: "la intelección es ciertamente un darse cuenta, pero es un darse cuenta de algo que está ya presente. En la unidad indivisa de estos dos momentos es en lo que consiste la intelección» ${ }^{102}$. Ahí, en la unidad del «darse cuenta»y «presente algo» en el «estar», reside la índole del acto intelectivo. Ese «estar» que constituye la unidad del «darse cuenta» $\mathrm{y}$ "presente algo» es un carácter físico y no meramente intencional del acto. Zubiri, recogiendo estos dos momentos, señala que la unidad de ellos es una unidad física, es lo que expresa con el estar.

El problema es analizar qué significa ese «estar físico» como unidad del «darse cuenta» y «algo presente». El propio Zubiri nos da claves al precisar ese «estar físico» en oposición a «meramente conceptivo» y a la «intencionalidad». Entendiendo físico, dice Zubiri, "como algo que no es meramente conceptivo». Añade posteriormente que el estar, que es el momento de unidad del «darse cuenta» y del "presente algo» expresa que el acto intelectivo es un "estar» en el cual estoy «con» la cosa y «en» la cosa (no «de» la cosa), y en que la cosa está «quedando» en la intelección. La intelección como acto no es formalmente intencional. Es un físico «estar» ${ }^{103}$.

Para precisar ese «estar físico» vamos a contraponerlo a lo producido (el máximo de la representación para Zubiri y Heidegger y, para este último el fin de la metafísica occidental), a lo conceptivo y a lo intencional.

Lo producido, Zubiri, habla de lo «engendrado conceptivamente» hace referencia a que lo inteligido está en la inteligencia como «engendrado conceptivamente». Es el caso de Hegel. Estar en la inteligencia es «estar engendrado conceptivamente» y la esencia del acto intelectivo es "pensar concipiente» (begreiffendes Denken).

\footnotetext{
100 Cfr. ZuBIRI, X., IRE. p. 21.

101 Ibíd. p. 22.
}

102 Ibíd. Preferimos esta formulación, aunque no hay formulación perfecta, a la que aparece en la misma página unas líneas más abajo: «En la intelección me "está" presente algo de lo que yo "estoy" dándome cuenta. La unidad indivisa de estos dos momentos consiste en el estar". Aquí aparece el «yo» que, con razón, podría ser considerado un transcender metafísico hacia una sustantividad.

103 Ibid. pp. 22-23. 
Lo conceptivo, por ejemplo en Kant, ha entendido que lo inteligido está presente a la inteligencia como «estando puesto» ${ }^{104}$. El estar de la "cosa» (en el sentido amplio que señalábamos al principio) sería «un estar puesto por la inteligencia para ser inteligido». De este modo lo que media la separación o distancia entre el inteligir y el sentir como facultades operativas (distancia que nunca es aclarada) es la "posición». Posición es que «la cosa» para ser inteligida tiene que estar propuesta a la inteligencia (ese estar propuesta es propiamente el acto de la facultad sensitiva). Es la idea de Kant según Zubiri. «Estar presente» es «estar puesto» y la esencia de la intelección sería «posicionalidad».

Lo intencional entiende el estar de lo inteligido en la inteligencia como «ser término de la conciencia», presencia intencional. Es la idea de Husserl. Estar presente aquí no es «estar puesto" por la sensibilidad a la inteligencia, sino «ser término intencional de la conciencia» ${ }^{105}$. Por ser término de la inteligencia se entiende que «lo inteligido», la cosa» es un mero «referirme a ella». Lo inteligido como "correlato» de esta intención. Estar presente es «estar intencionado». La esencia de la intelección sería intencionalidad.

El estar físico por lo tanto no es ni «concebido», ni «posicional», ni «intencionado», es un estar de la cosa misma, desde ella misma, en el acto intelectivo y al mismo tiempo un estar del acto intelectivo con la cosa misma. La cosa ni está puesta ni está intencionada en primera línea. Es un estar presente la cosa misma en su plenitud.

A esto le llama Zubiri aprehensión. Ese acto de aprehensión (acto único) tiene dos momentos: el sentir y el inteligir. Momentos del único acto, no yendo más allá del acto, actos de unas facultades metafísicamente propuestas para explicar el acto: «el sentir humano y la intelección no son dos actos numéricamente distintos, cada uno completo en su orden, sino que constituyen dos momentos de un solo acto de aprehensión» ${ }^{106}$.

Será, por lo tanto, en la misma aprehensión entendiendo por ella «un "estar" en que yo estoy "con" la cosa (...) y "en" que la cosa está "quedando" en la intelección " ${ }^{107}$ dónde habrá que buscar esos dos momentos suyos (no en unas supuestas facultades).

Si miramos al momento sentiente, este ha sido subsumido a lo largo de la historia de la filosofía, según Zubiri, en dos conceptos: el sentir como intuición y el sentir como impresión (Eindruck).

Desde la primera concepción se dice que el sentir es «la intuición primera y elemental con la que las cosas se nos dan: intuiri, ver» ${ }^{108}$. La intuición, como definición del sentir, el darse inmediato y directamente de algo. ¿Sirve esto

\footnotetext{
$104 \quad$ Ibíd. p. 135.

105 Ibid. p. 135.

$106 \quad$ Ibíd. p. 12.

107 Ibid. p. 23.
}

108 Cfr. Zubiri, X. (1995). Problemas fundamentales de la metafísica occidental. Madrid: Alianza Editorial. Fundación Xavier Zubiri. p. 329. A partir de ahora lo citaremos como PFMO. 
tan vago como que las cosas se nos dan intuitivamente para caracterizar el sentir? Zubiri piensa que no. Lo que expresa esta intuición, a juicio de Zubiri, es «una especie de conocimiento diminuto, respecto del cual la inteligencia posee el concepto plenario, tiene la intelección plenaria montada sobre esa» ${ }^{109}$ intuición. Por cierto, Zubiri señala que esto no puede ser tampoco el carácter esencial de la aprehensión primordial de realidad: una especie de conocimiento diminuto y concentrado que después se va desplegando en las otras modalidades de la inteligencia (esto sería una recaída en una especie de realismo, a lo mejor no ingenuo, más moderado, crítico, pero realismo al fin y al cabo).

Desde la segunda concepción se nos dice que lo que la intuición nos da «algo que es precisamente la impresión, la afección (Eindruck)» ${ }^{110}$. Es la concepción de Kant. Sería intuición en impresión. ¿Qué entiende Kant por impresión? Parece que lo asume de los empiristas señalando que la impresión es «una afección del sujeto» ${ }^{111}$. Zubiri se pregunta que si la impresión sólo fuese una afección del sujeto, cómo se las podría arreglar Kant "para componer todo el orden categorial para que de unas afecciones, que no son más que afecciones en impresión, pueda constituirse el mundo de los objetos, del que vive el hombre su vida cotidiana y sobre el cual está montada la ciencia. Esto resultaría difícil explicar». A no ser, y esta es la tesis de Zubiri sobre la filosofía moderna a mi modo de ver, que el mundo sea re-presentado y producido (vor-stellen y herstellen), o con otros nombres constituido/construido, por una inteligencia que se sabe a sí misma como concipiente con una mínima base de afección (una afección que es un sentirse afectado). Es decir, y esta es la propuesta de Zubiri frente a Husserl, la entificación de la realidad y su logificación (el objetivismo fisicalista y la subjetividad trascendental de Husserl) tiene aquí su raíz más profunda y no en la imposibilidad de la metafísica ante la ciencia galileana. Lo cual no resta ni un ápice al problema de la influencia de la ciencia moderna en la filosofía.

Zubiri acepta que el sentir sea impresión como afección del sentiente, pero lo que indica es que en el sentir hay dos momentos más que no han sido reconocidos: el momento de alteridad y el momento de fuerza impositiva. Me interesa resaltar el segundo en función de mi estudio. Zubiri señala que la impresión es afección, pero una afección tal «que se me hace presente un término (aquello que me afecta), se me hace presente la alteridad» ${ }^{112}$. Debido al momento de alteridad de la impresión sentiente se me hace presente «algo otro en afección». Eso algo otro presente en afección es lo que Zubiri llama «nota», entendiendo por nota lo meramente notado en la impresión en cuanto otro sin confundirlo con cualidades o propiedades ${ }^{113}$. Por lo tanto la impresión es afección de alteridad. Lo que hay que aclarar es que es esa alteridad. La alteri-

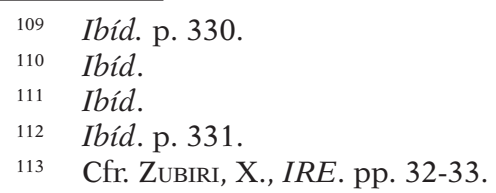


dad, como momento de la impresión sentiente, no es solo ni principalmente la alteridad de los contenidos con los que se me presenta algo, ya que cualquier contenido que se me presente en impresión sensible o en el momento sentiente del acto intelectivo lo es desde un "modo previo de enfrentarse con la cosa» ${ }^{114}$. Hay un modo de enfrentarse con la cosa que es de «forma estimúlica» (lo que Zubiri llamará formalidad estimúlica). En la forma estimúlica nos enfrentamos en nuestras impresiones con la alteridad de una forma muy concreta: lo otro presente en la impresión afectándome (lo notado, de nota en el sentido anteriormente expresado) lo está meramente "como un signo objetivo de las reacciones que pueda tener», que pueda suscitar.

Entonces ¿cuál es el momento intelectivo del único acto? El modo de enfrentarse con la cosa como «realidad estimulante» (lo que Zubiri llamará formalidad de realidad). En el modo de enfrentarse con la cosa como "realidad estimulante» lo notado no queda como signo de nada sino que queda como «en propio», es lo que Zubiri va a llamar «de suyo»; está afectándonos en la impresión pero lo notado no está (en el sentido de estar anteriormente aclarado) tan sólo «como mera alteridad perteneciente signitivamente al proceso del sentir (es decir, como signo que suscita una respuesta o unas reacciones, como estímulo), sino de una alteridad que como tal no pertenece sino (a lo notado) por sí mismo» ${ }^{115}$. De este modo lo notado queda en el sentir intelectivo como otro desde sí mismo. Eso es la formalidad de realidad.

Así, al ser el acto intelectivo sentiente un único acto, este puede ser visto desde dos vertientes pero que tienen unidad en el "estar» como lo vimos antes: «Ese acto de impresión de realidad, por lo que tiene de impresión es sensitivo; por lo que tiene de realidad es intelectivo» ${ }^{116}$.

$\mathrm{Y}$ ahora podemos precisar ese «estar». El acto intelectivo no es ni concipiente, ni conceptivo, ni intencional en esencia, sino que el acto intelectivo tomado «simpliciter - en tanto que inteligencia sentiente- (...) es pura y simple "actualización" de lo inteligido» ${ }^{117}$. ¿Qué es actualidad?:

"Actualidad" no tiene aquí el sentido que tiene en Aristóteles la enérgeia, el acto; no me refiero al acto de una potencia; me refiero a lo que significa el término cuando se dice que algo tiene mucha actualidad en este momento. "Actualidad" en este sentido no es el acto de una potencia, sino un modo de presencia y presentación. En este sentido, digo que lo propio de la inteligencia no es "darse-cuenta-de" ni forjar una "re-presentación", sino pura y simplemente que las cosas le estén "actualmente" presentes, que adquieran "actualidad" en la propia inteligencia. Ahora bien, esta actualidad es actualidad de una cosa como real; entonces, en su presentación misma, lo real en impresión se nos presenta como algo que es prius a la presentación misma. Lo cual significa, claro está, que esta inteligencia no es realidad, por lo

\footnotetext{
114 Cfr. Zubiri, X., PFMO. p. 331.

115 Cfr. Zubiri, X., IRE. pp. 56-57.

116 Cfr. ZuBIRI, X.. PFMO. p. 336.

117 Ibíd.
} 
pronto, más que respectivamente a las cosas reales. Es decir, la conciencia carece de sustantividad y la inteligencia misma sólo tiene sustantividad en respectividad con todas las cosas; no es algo "ab-soluto" »"

Estos son los puntos clave del texto anterior brevemente comentados:

1. Actualidad no es el acto (enérgeia) de una potencia como en Aristóteles.

2. Por lo tanto lo propio de la inteligencia no es ni forjar representaciones, ni «darse-cuenta-de». Como si «darse-cuenta-de» o forjar representaciones fueran actos de la potencia o facultad intelectiva que se ejecutan ante la presencia de algo ofrecido a esa facultad por la sensibilidad.

3. Esto significa que la inteligencia no es realidad, no hay que sustantivizarla.

4. Actualidad es un modo de presencia y presentación: las cosas le están actualmente presentes a la inteligencia.

5. Ese estar presentes actualmente de las cosas a la inteligencia, es un estar presentes de las cosas como reales.

6. Por lo tanto en esa presentación, lo real presente en impresión (es presentación sentiente), se nos presenta como algo "prius» a la presencia misma. No como algo «prius» anterior a la presencia, sino como algo «prius» en la presencia (diferencia entre realismo y «reismo»).

7. La inteligencia solo tiene sustantividad en respectividad con todas las cosas: no es algo ab-soluto (nada de inteligencia concipiente, Hegel, o pura, Kant).

Si la inteligencia o el acto intelectivo es capaz de abrirse al objeto que se le va a hacer presente antes de toda representación, es decir, abrirse a «la cosa primaria y primitivamente presente» ${ }^{119}$ es porque la inteligencia, o el acto intelectivo, es primariamente una manera de haberselas con las cosas, presentándose ellas mismas de alguna forma, no puede ser entendida más que secundariamente como "facultad de producir representaciones o conceptos». Si se ha concebido así es porque se ha planteado desde los orígenes una dualidad de actos, soportados por facultades, entre inteligir y sentir, no originaria.

Esta forma de hacerse presente las cosas a la inteligencia, o a los actos intelectivos, es, como hemos visto, la «formalidad de realidad». Lo que distingue a esta formalidad del puro sentir, del estímulo: «es que, mientras el estímulo tiene presentes las cosas por algo que suscita una reacción, la inteligencia tiene las cosas, como estímulos si se quiere, pero como estímulos «reales»: es la aprehensión de las cosas como reales» ${ }^{120}$. Es decir, mientras que en la "formalidad estimúlica» las "cosas» se agotan en suscitar una reacción, en la "formalidad de realidad» las cosas, aun suscitando una reacción, tienen un momento de realidad que habrá que mostrar.

Como la realidad primaria es realidad estimulante o realidad sentida. Esta forma primaria de realidad, «la aprehensión de las cosas como reales», significa

\footnotetext{
118 Cfr. Zubiri, X. CLF. p. 289.

119 Ibid.

$120 \quad$ Ibid. p. 288.
} 
que las cosas están presentes a la inteligencia en impresión. Es decir, la inteligencia es inteligencia sentiente. Esto quiere decir que no hay por un lado una sensibilidad que presenta las cosas a la inteligencia y una inteligencia que las conceptúa, «sino que entre sentidos e inteligencia constituyen un solo acto presentativo: la presentación de lo real en impresión» ${ }^{121}$. Esto no significa que no haya representaciones, sino que toda re-presentación de las cosas supone una presentación previa.

\section{Conclusiones desde el Laberinto}

\subsection{Sobre la génesis de la crisis de la razón en Husserl y Zubiri (El ovillo de Ariadna)}

Para Husserl la crisis de la razón filosófica es debida a que el ideal de la misma, forjado en la antigüedad y redescubierto en el renacimiento, no pudo mantenerse. Este ideal consistía en la existencia filosófica entendida como vida teorética. La teleología de esta vida teorética consiste en dar forma a la vida entera y al mundo que la circunda a partir de reglas fundadas en la razón pura (vida como racionalidad constituyente de sí misma y del mundo circundante). Este ideal se rompe por el surgimiento de la ciencia moderna que culmina con las ciencias positivas. Estas reducen los problemas de la vida teorética, de la razón en su plenitud, a problemas de hechos. De este modo los problemas sobre el modo de comportamiento del hombre frente al mundo humano y extramundano se desvanecen. El hilo de Ariadna estará en seguir el ovillo de existencia filosófica como vida teorética capaz de dar reglas fundadas en una razón pura, que como veremos se formulará de otra manera: como subjetividad trascendental.

Para Zubiri la crisis de la razón filosófica reside en un gigantesco proceso de entificación de la realidad. Por proceso de entificación se entiende el hecho de concebir el espacio, el tiempo, el ser e incluso la conciencia como entes en los cuales transcurren las cosas: todo ente se da en el espacio, transcurre en el tiempo, es una contracción o una concreción o un accidente del gran piélago del ser. En último término hasta la conciencia es un lugar, el lugar dónde todo ente es concebido, puesto, representado, es el receptáculo de todo el ente, del ser. Espacio, tiempo, ser y conciencia son pensados como entes y la raíz de esto está en la secularización del pensamiento antiguo y medieval cristiano. El hilo de Ariadna estará en seguir el ovillo de esa entificación de la realidad y en ver cómo puede desentificarse (si se nos permite la palabra) y las consecuencias que eso tendría para un nuevo comienzo filosófico.

121 Ibid. 


\subsection{El origen de la crisis de la razón filosófica en Husserl y Zubiri (En el corazón del laberinto: sacrificando al monstruo)}

Para Husserl la raíz de esa pérdida del ideal de la existencia filosófica está en la potencia de la ciencia galileana, una potencia no cuestionada en sus raíces y en sus fundamentos por la filosofía. Lo que ocurre con la ciencia galileana es la matematización del mundo circundante, siempre subjetivo-relativo, y, por lo tanto, su sometimiento, tanto en su espacio como en las cualidades secundarias (color, sonido, olor...), a una medida exacta. Es decir, sin ser plenamente consciente de la operación que subyace a ese planteamiento, la ciencia galileana ejerce la capacidad que tiene el pensamiento de, a partir de medidas y leyes aprióricas (constituidas por un proceso de idealización), moldear el mundo de la naturaleza, el mundo circundante. La filosofía intentó extender el método de la ciencia galileana al resto de los problemas filosóficos desvanecidos. Ante el fracaso de ese intento lo que se alcanzó es una subjetividad incapaz de recuperar el ideal de la existencia filosófica como vida teórica. Llegando a una situación de contraposición entre un objetivismo fisicalista (el de las ciencias positivas que las ciencias llamadas humanas también harán suyo) y un subjetivismo no suficientemente radical como para englobar un mundo circundante cada vez más abandonado a esas ciencias. En el corazón del laberinto Husserl ve una subjetividad debilitada, reducida y no consciente que como subjetividad no sólo constituye su vida interior, sino que siempre es subjetividad constituyente del mundo en su totalidad. El Minotauro del éxito de las ciencias positivas ha encerrado a la subjetividad en una subjetividad sin mundo, perdida y encerrada en su laberinto interior.

Para Zubiri la crisis de la razón filosófica es la pérdida de la realidad y esa pérdida se debe a la subjetividad (que para Husserl es el hilo de Ariadna). Es precisamente la realidad la que se ha perdido en el laberinto de la subjetividad, lo que conlleva una incapacidad de la filosofía para superar su crisis frente al éxito de las ciencias positivas (que aunque no sean totalmente conscientes de sus fundamentos no dejan una y otra vez de medirse con ella, con la realidad). La pérdida está provocada por la entificación de la conciencia que trae como consecuencia que la realidad es representación. Por representación entiende Zubiri que la conciencia como acto subjetivo de darse cuenta unifica, hace presente el ser con todas sus dimensiones espacio-temporales, lo constituye (en el modo más suave) o lo construye o concibe (en el caso más radical). En el corazón del laberinto Zubiri ve una subjetividad constituyente, que se representa el mundo. Ese es el Minotauro que es necesario sacrificar para superar una crisis de la razón filosófica que solo podrá revertirse con el hilo de Ariadna de la realidad aprehendida en el acto intelectivo.

\subsection{La superación de la crisis de la razón filosófica (Encontrando el camino)}

Para Husserl la salida del laberinto consiste en enrollar el mundo de la vida y el mundo de la realidad socialmente compartida sobre la subjetividad que lo 
anima y alienta. Es decir, descubrir cómo a la base del mundo de la vida y de las formas de praxis cultural (arte, religión, ciencia...) que son objetivaciones de él, está la subjetividad no empírica sino trascendental. El camino de salida está en un repliegue en la subjetividad trascendental.

Para Zubiri la salida del laberinto consiste en enrollar, plegar, unificar la inteligencia y la sensibilidad sobre el acto de inteligencia sentiente. No hay una conciencia sustantiva que ejecuta actos, que constituye mundo, sino un único acto intelectivo sentiente que puede ser consciente. Lo propio del acto intelectivo es un estar presente algo. Ese estar consiste en mera actualidad (que se opone entre otras cosas a que lo presente sea término de una conciencia constituyente, como piensa Husserl, término constituido por una subjetividad trascendental dicho de otro modo). La actualidad como esencia del acto intelectivo es la superación de todo pensamiento trascendental sin recaer en ningún tipo de realismo (clásico o crítico, que es lo mismo). El acto intelectivo por lo tanto no es forjador de representaciones, ni ser «consciente de» en primera línea. Es un mero estar presente de las cosas a la inteligencia. El camino de salida de la crisis de la razón filosófica está en un despliegue del acto intelectivo como actualidad de lo real en cuanto real.

Fundación Xavier Zubiri

afreundschaft@gmail.com

ÁNgEl GonZÁLEz PÉrez

[Artículo aprobado para publicación en este número extraordinario en noviembre de 2014] 